\title{
School-Ex 2.0 : de implementatie van ombuiggesprekken
}

Citation for published version (APA):

Verhagen, A. M. C., de Hoon, M. L. A., \& Meng, C. M. (2015). School-Ex 2.0 : de implementatie van ombuiggesprekken. ROA. ROA Reports No. 004 https://doi.org/10.26481/umarep.2015004

Document status and date:

Published: 01/01/2015

DOI:

10.26481/umarep.2015004

Document Version:

Publisher's PDF, also known as Version of record

\section{Please check the document version of this publication:}

- A submitted manuscript is the version of the article upon submission and before peer-review. There can be important differences between the submitted version and the official published version of record.

People interested in the research are advised to contact the author for the final version of the publication, or visit the DOI to the publisher's website.

- The final author version and the galley proof are versions of the publication after peer review.

- The final published version features the final layout of the paper including the volume, issue and page numbers.

Link to publication

\footnotetext{
General rights rights.

- You may freely distribute the URL identifying the publication in the public portal. please follow below link for the End User Agreement:

www.umlib.nl/taverne-license

Take down policy

If you believe that this document breaches copyright please contact us at:

repository@maastrichtuniversity.nl

providing details and we will investigate your claim.
}

Copyright and moral rights for the publications made accessible in the public portal are retained by the authors and/or other copyright owners and it is a condition of accessing publications that users recognise and abide by the legal requirements associated with these

- Users may download and print one copy of any publication from the public portal for the purpose of private study or research.

- You may not further distribute the material or use it for any profit-making activity or commercial gain

If the publication is distributed under the terms of Article $25 \mathrm{fa}$ of the Dutch Copyright Act, indicated by the "Taverne" license above, 


\section{SCHOOL-EX 2.0: DE IMPLEMENTATIE VAN OMBUIGGESPREKKEN}

- Een case studie bij drie mbo-bol niveau 2 opleidingen -

ROA-R-2015/4

Annelore Verhagen

Marloes de Hoon

Christoph Meng 


\section{Colofon}

(c) Researchcentrum voor Onderwijs en Arbeidsmarkt (ROA). Niets uit deze uitgave mag op enige manier worden verveelvoudigd zonder voorafgaande schriftelijke toestemming van de directeur van het ROA.

\section{Researchcentrum voor Onderwijs en Arbeidsmarkt}

School of Business and Economics

Maastricht University

\section{Vormgeving}

ROA secretariaat, Maastricht

\section{Verkoop}

Researchcentrum voor Onderwijs en Arbeidsmarkt email: secretary-roa-sbe@maastrichtuniversity.nl website: www.roa.nl

ISBN: 978-90-5321-540-1 


\section{INHOUD}

03 Methodologische aanpak

3.1 Verantwoording voor het selecteren van mbo-bol opleidingen

3.2 Selectie van interviewrespondenten

3.3 Verwerking van de interviews

04 Resultaten: De Implementatie van ombuiggesprekken in praktijk

4.1 De rol van de manier waarop mbo-scholen arbeidsmarktperspectieven bepalen

4.2 De verwachte mogelijkheid om jongeren om te buigen

4.3 Eventuele negatieve neveneffecten

05 Conclusie, discussie en een blik op de toekomst

5.1 De rol van de manier waarop mbo-scholen arbeidsmarktperspectieven bepalen

5.2 De verwachte mogelijkheid om jongeren om te buigen

5.3 Eventuele negatieve neveneffecten van ombuigen

5.4 Een blik op de nabije toekomst: Herziening kwalificatiedossiers mbo

5.5 Beschouwende discussie

BIJLAGE 1 Aanpak Jeugdwerkloosheid

BIJLAGE 2 Aantal vragenlijsten dat is verstuurd aan School-Ex contactpersonen en ingevuld door relevante actoren op mbo-scholen 



\section{1 \\ INLEIDING}

Het middelbaar beroepsonderwijs (mbo) bereidt mensen voor op de beroepspraktijk of een vervolgopleiding. Hoewel doorstroom mogelijk is, staat bij alle mbo-opleidingen de aansluiting met de praktijk voorop. De discussie over de macrodoelmatigheid ${ }^{1}$ van opleidingen wordt daarom blijvend gevoerd en leidde in 2007 tot een aanpassing van de Wet educatie en Beroepsonderwijs (WEB) en de instelling van een zorgplicht voor mbo-opleidingen. Deze zorgplicht houdt in dat onderwijsinstellingen enkel een opleiding mogen aanbieden als er na afronding van de opleiding voldoende arbeidsmarktperspectief is voor de deelnemers.

De recente economische crisis en de daaraan gerelateerde sterk oplopende jeugdwerkloosheid maken dat de zorgplicht des te meer aandacht verdient. In de Aanpak Jeugdwerkloosheid - dat als doelstelling heeft om de actuele jeugdwerkloosheid te bestrijden en toekomstige jeugdwerkloosheid te voorkomen - wordt het belang van een goede aansluiting tussen onderwijs en arbeidsmarkt dan ook expliciet benoemd. Om de doelstellingen van de Aanpak Jeugdwerkloosheid te bereiken worden de volgende actiepunten genoemd²:

- Ervoor zorgen dat jongeren de juiste opleiding volgen

- Ervoor zorgen dat jongeren hun opleiding afmaken

- Ervoor zorgen dat jongeren gemotiveerd kiezen voor een vervolgopleiding

Een belangrijk onderdeel van de Aanpak Jeugdwerkloosheid is het School-Ex Programma. Zowel het eerste School-Ex Programma in de periode 2009-2010 als het School-Ex 2.0 Programma (2013-2015) zijn in hoofdlijnen gericht op de registratie van toekomstplannen van mbo examenkandidaten en hen te stimuleren om door te studeren. Deze stimulans zou tijdens zogenaamde exitgesprekken moeten worden gegeven. Met het School-Ex 2.o Programma zijn daar de zogenaamde ombuiggesprekken aan toegevoegd. Deze gesprekken zijn ten eerste bedoeld om jongeren die zich aanmelden voor een mboopleiding met weinig arbeidsmarktperspectief in de regio te wijzen op de beperkte

1 'Macrodoelmatigheid' valt uiteen in drie delen (Eimers, 2012). Eén deel daarvan betreft de arbeidsmarktrelevantie van opleidingen, waarbij het gaat om hoe goed het opleidingenaanbod in een regio aansluit bij de regionale arbeidsvraag van werkgevers.

2 Zie Bijlage 1 voor een samenvatting van de Aanpak Jeugdwerkloosheid. 
arbeidsmarktperspectieven van de gekozen opleiding. Bovendien worden aanmelders in deze gesprekken gestimuleerd om serieus na te denken over het volgen van een andere opleiding met beter arbeidsmarktperspectief na afloop.

In 2014 is het eerste jaar van het School-Ex 2.0 Programma geëvalueerd (zie Meng, Verhagen, Korthals \& Huijgen, 2014). Deze evaluatie was grotendeels gebaseerd op een enquête onder verantwoordelijken van de 18 opleidingsdomeinen van mbo-scholen. ${ }^{3}$ Hieruit bleek ten eerste dat exitgesprekken op grote schaal werden gevoerd: $92 \%$ van de school-domein combinaties meldde dat exitgesprekken hadden plaatsgevonden in het schooljaar 2013/2014 en 70 procent van de gediplomeerde mbo'ers gaf aan minimaal één keer met een medewerker van school over zijn/haar toekomstplannen te hebben gesproken. ${ }^{4}$ Op basis van de beschikbare data kon echter niet worden aangetoond dat de introductie van het School-Ex 2.0 Programma tot een significante verandering van het aandeel mbo-gediplomeerden dat ging doorstuderen had geleid. Dit betekent dat er weliswaar geen significant effect van de introductie van het School-Ex 2.o Programma kon worden gevonden, maar niet per definitie dat exitgesprekken geen effect hebben op de kans dat mbo-gediplomeerden ervoor kiezen om door te studeren. Zo kwam uit het onderzoek naar voren dat aan verschillende onderwijsinstellingen al voorafgaand aan de start van het School-Ex 2.o Programma exitgesprekken werden gevoerd. Van de jongeren die aangaven een exitgesprek te hebben gehad, gaf een kwart aan dat hun vervolgstappen na afstuderen hierdoor zijn beïnvloed.

Ombuiggesprekken werden op veel minder grote schaal gevoerd, zo bleek uit de evaluatie van het eerste jaar van het School-Ex 2.o Programma: 51 procent van de schooldomein combinaties gaf aan dergelijke gesprekken te hebben gevoerd met de vmboinstromers in het mbo in het schooljaar 2013/2014. Dat niet binnen alle school-domein combinaties ombuiggesprekken zijn gevoerd is op zich niet zo verrassend, omdat er geen aanleiding is om ombuiggesprekken te voeren bij opleidingen met goede arbeidsmarktperspectieven. Van de school-domein combinaties die naar eigen inzicht opleidingen aanbieden met weinig arbeidsmarktperspectief, maar desondanks geen ombuiggesprekken voerden, gaf 23 procent aan dat ze geen gesprekken voerden omdat ze deze 'niet nuttig' vonden en 21 procent gaaf aan dat ze geen gesprekken voerden omdat dat ten koste gaat van de instroom in de opleiding. Ook bleek uit de analyses dat slechts 37 procent van de school-domein combinaties die wel ombuiggesprekken voerden, er vanuit ging dat de gevoerde ombuiggesprekken effectief waren in de zin dat ze als gevolg hadden dat ze leerlingen naar opleidingen met betere arbeidsmarktperspectieven leidden.

De evaluatie van zowel de exit- als de ombuiggesprekken toonde aan dat er nog veel onduidelijkheid is over de exacte vorm en inhoud van deze gesprekken en onder welke

3 In totaal zijn er in het mbo 685 school-domein combinaties. Aan de enquête hebben 320 school-domein combinaties deelgenomen.

4 Naast een enquête onder verantwoordelijken van de opleidingsdomeinen binnen de scholen heeft in het kader van de evaluatie van het eerste jaar van School-Ex 2.0 Programma ook een enquête onder recent mbo-gediplomeerden van het schooljaar 2013-2014 plaatsgevonden. 
voorwaarden ze effectief zijn (m.a.w. het gewenste effect hebben). Voor de voorliggende evaluatie van het tweede jaar van het School-Ex 2.o Programma is daarom een verdiepende kwalitatieve evaluatie uitgevoerd. Hiervoor is het noodzakelijk om de evaluatie van het tweede jaar van het School-Ex 2.o Programma verder af te bakenen. Deze afbakening houdt ten eerste in dat deze evaluatie zich richt op de ombuiggesprekken en de exitgesprekken buiten beschouwing laat. Daarnaast is ervoor gekozen om de tweede evaluatie volledig te richten op mbo-bol niveau 2 opleidingen. ${ }^{5}$

Het doel van deze evaluatie van het tweede jaar van het School-Ex 2.0 Programma is om meer inzicht te verkrijgen in de implementatie van ombuiggesprekken in mbo-bol niveau 2 opleidingen. De tweeledige hoofdvraag die daarbij gesteld wordt is als volgt:

Onder welke voorwaarden is het volgens relevante actoren op mbo-scholen mogelijk om jongeren die zich aanmelden voor mbo-bol niveau 2 opleidingen met weinig arbeidsmarktperspectief in de regio te stimuleren om hun studiekeuze te wijzigen en te kiezen voor een mbo-niveau 2 opleiding met beter arbeidsmarktperspectief, en welke argumenten worden gehanteerd om niet om te buigen?

Het rapport is als volgt opgebouwd. In Hoofdstuk 2 staan we kort stil bij de beleidsachtergrond van ombuiggesprekken en presenteren we een aantal randvoorwaarden voor een succesvolle implementatie van ombuiggesprekken. In Hoofdstuk 3 presenteren we de methodologische aanpak van het onderzoek en staan we kort stil bij de vraag hoe bepaald kan worden wat 'weinig' arbeidsmarktperspectief is. In Hoofdstuk 4 worden de resultaten van het onderzoek besproken, waarbij paragraaf 4.1 ingaat op de rol van de manier waarop mbo-scholen arbeidsmarktperspectieven bepalen, paragraaf 4.2 de verwachte mogelijkheid om jongeren om te buigen behandelt, en in paragraaf 4.3 eventuele negatieve neveneffecten worden besproken. In Hoofdstuk 5 wordt op basis van de resultaten geconcludeerd in hoeverre er aan de randvoorwaarden voor een succesvolle implementatie van ombuiggesprekken wordt voldaan, waarna we vooruitblikken op de nabije toekomst en nagaan hoeverre de herziening van de kwalificatiedossiers in het mbo gerelateerd is aan de bevindingen van dit onderzoek. Tot slot biedt Hoofdstuk 5 een beschouwende discussie.

\section{Dankwoord}

Dit onderzoek was niet mogelijk geweest zonder de medewerking van mbo-instellingen. We willen hierbij dan ook uitdrukkelijk de mbo-instellingen, en in specifiek de betrokken medewerkers, bedanken die a) de internet enquête hebben ingevuld en b) die op korte termijn bereid waren ons te ontvangen voor uitgebreide interviews. Een speciaal woord van dank wordt daarna gericht aan de leden van de begeleidingscommissie: drs. drs. Bernard Verlaan, drs. Andre de Moor (allen werkzaam bij het Ministerie van Onderwijs, Cultuur en Wetenschap), drs. Maurice Doll (werkzaam bij het Ministerie van Sociale Zaken en Werkgelegenheid), drs. Huib van der Kroon (Ministerie van Economische 
Zaken), Pierre Veelenturf (werkzaam bij de MBO Raad) en Jaap-Jan Bakker (werkzaam bij de Dienst Uitvoering Onderwijs). 


\section{2 \\ OMBUIGGESPREKKEN: BELEIDSACHTERGROND}

Om de hoofdvraag te kunnen beantwoorden is het ten eerste van belang om stil te staan bij de beleidstheorie van het School-Ex 2.o Programma, en ombuiggesprekken in het bijzonder. Als basis hiervoor dienen de brief van de ministers van SZW en OCW aan de Tweede Kamer d.d. 05 maart 2013 betreffende de Aanpak Jeugdwerkloosheid ${ }^{6}$ en de tijdelijke regeling School Ex 2013-2014.?

Zoals eerder gesteld is het doel van het School-Ex 2.0 Programma om jeugdwerkloosheid te voorkomen en de arbeidsmarktkansen van mbo'ers te vergroten. De middelen die daarvoor worden ingezet zijn exitgesprekken en ombuiggesprekken. Dit onderzoek richt zich op de implementatie van de ombuiggesprekken, die eraan moeten bijdragen dat instromers in het mbo kiezen voor opleidingen met goed arbeidsmarktperspectief in de regio. Ombuiggesprekken hoeven per definitie alleen te worden geïmplementeerd bij opleidingen met weinig arbeidsmarktperspectief in de regio. Tijdens een ombuiggesprek dienen jongeren erop gewezen te worden dat de gekozen opleiding weinig arbeidsmarktperspectief in de betreffende regio heeft, en moeten zij (op een niet nader gedefinieerde manier) worden gestimuleerd om na te denken over het volgen van een opleiding met beter arbeidsmarktperspectief. Schema 1 geeft een weergave van het in het beleid veronderstelde conceptuele model van ombuiggesprekken.

$6 \quad$ Kamerstukken II, 2013-20626.

7 Staatscourant 2013 nr. 24075, 29 augustus 2013. 
SCHEMA 1 Beleidstheorie ombuiggesprekken - Conceptueel model

MBO-scholen evalueren het opleidingsaanbod (van zichzelf en andere scholen) m.b.t. arbeidsmarktperspectieven in de regio MBO-scholen voeren ombuigingsgesprekken met VMBO'ers die zich hebben aangemeld voor opleidingen met slechte arbeidsmarktperspectieven

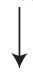

VMBO'ers die zich aangemeld hebben voor opleidingen met slechte arbeidsmarktperspectieven hebben kennis van deze slechte perspectieven, en van de (betere) arbeidsmarktperspectieven

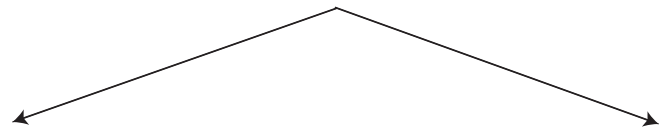

Het percentage VMBO'ers dat zich aanmeldt voor

Het percentage VMBO'ers dat zich aanmeldt voor opleidingen met slechte arbeidsmarktperspectieven neemt af

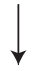

Het percentage afgestudeerden van vervolgopleidingen met slechte arbeidsmarktperspectieven neemt af opleidingen met goede arbeidsmarktperspectieven neemt toe

Het percentage afgestudeerden van vervolgopleidingen met goede arbeidsmarktperspectieven neemt toe

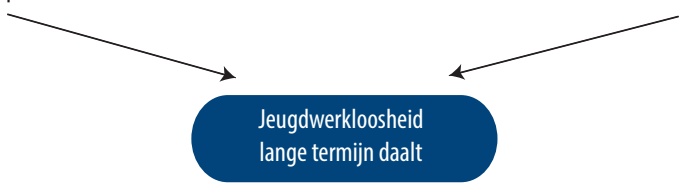

Met het voorliggende onderzoek wordt beoogd meer inzicht te verkrijgen in de veronderstelde mechanismen die zijn weergegeven in schema 1. Hoe wordt bijvoorbeeld bepaald of een opleiding 'weinig' of 'beter' arbeidsmarktperspectief heeft, en hanteren scholen daarbij wel dezelfde criteria? Is het eigenlijk wel zo vanzelfsprekend dat scholen jongeren proberen om te buigen zodra zij ervan overtuigd zijn dat een bepaalde opleiding weinig arbeidsmarktperspectief in de regio heeft, of zijn er argumenten om dit (desondanks) niet te doen? Zijn de arbeidsmarktperspectieven van een opleiding doorslaggevend voor de studiekeuze van een vmbo'er, of zijn er andere factoren/personen die een belangrijke(re) rol spelen? Dergelijke vragen tonen aan dat aan een aantal voorwaarden moet worden voldaan om de implementatie van ombuiggesprekken op mbo-bol niveau 2 succesvol te laten zijn (zie tekstbox 1). 
TEKSTBOX 1 Voorwaarden voor een succesvolle implementatie van ombuiggesprekken in mbo-bol niveau 2

De rol van de manier waarop mbo-scholen arbeidsmarktperspectieven bepalen

1. Relevante actoren op mbo-scholen zijn ervan overtuigd dat zij één of meerdere mbo-bol niveau 2 opleidingen aanbieden die weinig arbeidsmarktperspectief in de regio hebben, en deze overtuiging is gebaseerd op een betrouwbare indicator.

2. Relevante actoren op mbo-scholen zijn ervan overtuigd dat er in de regio mbo-niveau 2 opleidingen worden aangeboden waarvoor de arbeidsmarktperspectieven beter zijn, en deze overtuiging is gebaseerd op een betrouwbare indicator.

3. Het (beperkte) arbeidsmarktperspectief van een mbo-bol niveau 2 opleiding is voor relevante actoren op mbo-scholen de doorslaggevende factor bij het bepalen van het aantal leerlingen dat $\mathrm{kan} / \mathrm{mag}$ instromen in die opleiding.

\section{De verwachte mogelijkheid van ombuigen}

4. Relevante actoren op mbo-scholen zijn ervan overtuigd dat jongeren die zich hebben aangemeld voor een mbo-bol niveau 2 opleiding met weinig arbeidsmarktperspectief overtuigd kunnen worden om hun studiekeuze te wijzigen, en wel dusdanig dat zij in plaats daarvan een mbo-niveau 2 opleiding met beter arbeidsmarktperspectief kiezen en afronden.

5. Het arbeidsmarktperspectief van een mbo-opleiding is voor jongeren die willen instromen in het mbo-bol niveau 2 de doorslaggevende factor bij het maken van een studiekeuze.

6. Het studiekeuzeproces van jongeren is op zijn vroegst beëindigd op het moment dat ze worden ingeschreven bij een bepaalde opleiding.

\section{Eventuele negatieve neveneffecten van ombuigen}

7. Het stimuleren van leerlingen die zich hebben aangemeld voor een mbo-bol niveau 2 opleiding met weinig arbeidsmarktperspectief om hun studiekeuze te wijzigen heeft geen negatieve neveneffecten die volgens relevante actoren op mbo-scholen zwaarder wegen dan het positieve effect van betere arbeidsmarktperspectieven voor de toekomstige gediplomeerden.

\section{De rol van de manier waarop mbo-scholen arbeidsmarktperspectieven bepalen}

Ten eerste is het voor de succesvolle implementatie van ombuiggesprekken bij mbo-bol niveau 2 opleidingen noodzakelijk dat de relevante actoren op mbo-scholen ervan overtuigd zijn dat hun school mbo-bol niveau 2 opleidingen aanbiedt met weinig arbeidsmarktperspectief in de regio. Ombuiggesprekken vinden immers alleen plaats bij opleidingen met weinig arbeidsmarktperspectief. De term 'overtuigd' wordt hier bewust gebruikt, omdat er (nog) geen landelijk vastgestelde definitie van 'weinig' arbeidsmarktperspectief is, waardoor mbo-scholen enige vrijheid hebben in de keuze voor welke indicator ze hanteren om arbeidsmarktperspectieven te bepalen. De assumptie is dat relevante actoren hun beoordeling van de arbeidsmarktperspectieven van opleidingen baseren op bepaalde bronnen zoals bijvoorbeeld op arbeidsmarktprognoses, op hun eigen monitoring van werkloosheid onder hun afgestudeerden, of op het aantal 
beschikbare stageplaatsen. Wil ombuigen succesvol zijn, dan is het noodzakelijk dat de door deze bronnen vastgestelde arbeidsmarktperspectieven betrouwbaar zijn.

Een tweede voorwaarde voor een succesvolle implementatie van ombuiggesprekken bij mbo-bol niveau 2 opleidingen is dat de relevante actoren ervan overtuigd zijn dat er mbo-niveau 2 opleidingen zijn waar naartoe omgebogen zou moeten worden, dat wil zeggen opleidingen waarbij de arbeidsmarktperspectieven 'beter' of zelfs 'goed' zijn. Als niet aan deze voorwaarde wordt voldaan, betekent dit dat de actoren er niet van overtuigd zijn dat er mbo-niveau 2 opleidingen zijn met betere arbeidsmarktperspectieven, waardoor ombuigen huns inziens nutteloos zal zijn en daardoor niet plaats zal vinden. Ook bij deze voorwaarde is het noodzakelijk dat de actoren zich baseren op betrouwbare indicatoren bij het bepalen van 'betere' arbeidsmarktperspectieven.

Ook als de actoren onderkennen dat een bepaalde mbo-bol niveau 2 opleiding weinig arbeidsmarktperspectief heeft en dat de perspectieven bij andere mbo-niveau 2 opleidingen beter zijn, is het mogelijk dat er geen activiteiten worden ondernomen om het aantal instromende leerlingen in de opleiding met weinig arbeidsmarktperspectief te reduceren. Het bepalen van het aantal instromende leerlingen kan immers afhankelijk zijn van meer factoren dan enkel het (beperkte) arbeidsmarktperspectief van een opleiding. Voor een succesvolle implementatie van ombuiggesprekken is het noodzakelijk dat - van alle factoren die de vaststelling van het aantal leerlingen dat in de opleiding mag instromen beïnvloeden - de arbeidsmarktperspectieven de doorslag geven, of dat de overige invloedrijke factoren het aantal instromende leerlingen op dezelfde manier beïnvloedt. Wanneer dit niet het geval is, is de kans groot dat er meer leerlingen tot de opleiding zullen worden toegelaten dan waar naar verwachting arbeidsmarktperspectief voor is, wat indruist tegen de doelstelling van het School-Ex 2.o Programma.

\section{De verwachte mogelijkheid om jongeren om te buigen}

Indien er aan de eerste drie voorwaarden is voldaan, en de relevante actoren ervan overtuigd zijn dat bepaalde mbo-bol niveau 2 opleidingen weinig arbeidsmarktperspectief in de regio hebben maar dat er in hun regio ook opleidingen op dat niveau worden aangeboden waarvoor de perspectieven beter zijn, is het vervolgens van groot belang dat de relevante actoren er vanuit gaan dat het mogelijk is om jongeren om te buigen. Dit is de kernassumptie waar het onderdeel 'ombuiggesprekken' van het School-Ex 2.0 Programma op rust. Naar verwachting zal de haalbaarheid van deze voorwaarde sterk afhankelijk zijn van de opleidingssector van de opleiding met slechte dan wel goede arbeidsmarktperspectieven. Een ombuiging op mbo-niveau 2 van Helpende Zorg \& Welzijn naar Betonstaalverwerker lijkt bijvoorbeeld wat vergezocht. De vraag is daarom wat alternatieven zijn voor de opleidingen met weinig arbeidsmarktperspectief, en of dit opleidingen zijn waarbij de arbeidsmarktperspectieven beter of zelfs goed zijn.

Bovenstaande geldt in zekere zin ook voor de leerlingen die instromen in het mbo. Ook al zijn zij op de hoogte van het beperkte arbeidsmarktperspectief van de oplei- 
ding waarvoor zij zich hebben aangemeld, en weten zij welke alternatieve opleidingen betere perspectieven bieden; dat hoeft niet direct te leiden tot een wijziging van de studiekeuze. Een studiekeuze kan immers gebaseerd zijn op meer dan alleen de arbeidsmarktperspectieven, en zo lang die andere factoren zwaarder wegen dan de arbeidsmarktperspectieven, en deze overige factoren de studiekeuze bewegen richting een opleiding met weinig arbeidsmarktperspectief, is het onwaarschijnlijk dat de aankomend mbo-student zijn/haar studiekeuze zal veranderen richting een opleiding met beter arbeidsmarktperspectief.

Aan het onderdeel Ombuiggesprekken van het School-Ex 2.o Programma ligt bovendien de assumptie ten grondslag dat het studiekeuzeproces van jongeren op zijn vroegst is beëindigd op het moment dat ze worden ingeschreven bij een bepaalde opleiding. Alleen onder deze voorwaarde is het mogelijk om in de periode tussen de aanmelding en de formele inschrijving de studiekeuze te beïnvloeden. Ombuiging vindt immers per definitie ná de aanmelding plaats. Dit betekent dat ombuiging - zoals bedoeld in het School-Ex 2.o programma - niet kan plaatsvinden als het studiekeuzeproces al is beëindigd op/voor het moment dat jongeren zich hebben aangemeld voor een bepaalde opleiding.

\section{Mogelijke negatieve neveneffecten van ombuigen}

Tot slot is het mogelijk dat negatieve neveneffecten van ombuigen worden ervaren of voorzien. Voor een succesvolle implementatie van ombuiggesprekken is het noodzakelijk dat voor de relevante actoren deze voorziene nadelen van ombuigen minder zwaar wegen dan de voordelen van ombuigen (d.w.z. betere arbeidsmarktperspectieven voor toekomstige gediplomeerden). Als het omgekeerde het geval is vinden de actoren het naar verwachting onwenselijk om jongeren om te buigen. 



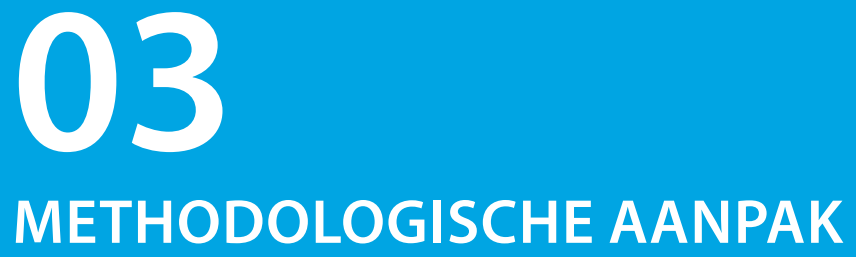

In dit hoofdstuk bespreken we ten eerste de selectie van mbo-bol niveau 2 opleidingen die in dit onderzoek centraal staan. Deze keuze wordt vervolgens verantwoord aan de hand van de publicatie Macrodoelmatigheid mbo: Inkadering arbeidsmarktperspectief (Cörvers, de Hoon \& Meng, 2014). Ten tweede wordt toegelicht hoe de interviewrespondenten zijn geselecteerd, en tot slot geven we een korte uitleg over de wijze waarop de interviews zijn verwerkt.

\subsection{Selectie van opleidingen}

Op basis van registerdata van DUO kan in alle 35 arbeidsmarktregio's voor elke mbo-bol niveau 2 beroepsopleiding ${ }^{8}$ die in die regio wordt aangeboden het percentage gediplomeerden dat één jaar na afstuderen ten minste 12 uur per week werkzaam is worden berekend (degenen die zijn gaan doorleren worden daarbij buiten beschouwing gelaten). Zodoende ontstaat een lijst waarin voor elke opleiding-regio-cluster het percentage ${ }^{9}$ werkenden wordt weergegeven. Tabel 1 geeft een overzicht van de mbo-bol niveau 2 opleidingen die voorkomen in de lijst van de $10 \%$ slechtst scorende opleiding-regioclusters voor wat betreft het percentage werkenden. Voor deze beroepsopleidingen is weergegeven hoe groot het landelijk percentage werkenden onder de gediplomeerden van de betreffende opleiding is (één jaar na afstuderen). Het aandeel werkenden van een beroepsopleiding verschilt in de meeste gevallen aanzienlijk tussen de verschillende arbeidsmarktregio's, getuige de range die in de vierde kolom is gegeven. Zo varieert het percentage werkenden onder gediplomeerden van Administratief medewerker van 36 procent in de slechtst scorende regio tot 71 procent in de best scorende regio.

8 De beroepsopleidingen die in het schooljaar 2012/2013 minder dan 2.0 schoolverlaters afleverden worden daarbij buiten beschouwing gelaten.

9 De grens van 12 uur per week is daarbij gebaseerd op basis van de tot eind 2014 geldende Nederlandse definitie van de beroepsbevolking. Vanaf 1 januari 2015 hanteert het CBS ook voor Nederland de internationale definitie van 1 uur per week als minimum om tot de werkzame beroepsbevolking te behoren. Het is momenteel nog onduidelijk in hoeverre deze verandering ook in de zcrgplicht 'arbeidsmarktrelevantie' voor de mbo scholen doorgevoerd wordt. Een verlaging van de uur grens leidt tot een algemene verbetering van de indicator 'arbeidsmarktrelevantie' voor alle opleidingen. Echter, deeltijd functies voor 1-11 uren per week zijn tegelijkertijd functies met in de regel een uiterst zwakke positie op de arbeidsmarkt (zie Schoolverlaters tussen onderwijs en arbeidsmarkt 2014) . 
In de laatste twee kolommen is voor elke mbo-bol niveau 2 beroepsopleiding weergegeven in hoeveel arbeidsmarktregio's deze werd aangeboden in schooljaar 2012/2013, en in hoeveel van deze arbeidsmarktregio's de betreffende beroepsopleiding tot de $10 \%$ slechtst scorende beroepsopleidingen behoorde. Administratief Medewerker wordt bijvoorbeeld in 25 arbeidsmarktregio's aangeboden, en in de lijst van de 10\% slechtst scorende opleiding-regio-clusters voor wat betreft het aandeel werkenden komt Administratief Medewerker 21 keer voor.

In dit onderzoek wordt de implementatie van ombuiggesprekken bij drie mbo-bol niveau 2 opleidingen geëvalueerd, namelijk

- Administratief Medewerker (crebo 90471 [Bedrijfsadministratief medewerker] / crebo 90472 [Secretariaeel medewerker] / crebo 90473 [Telefonist/receptionis])

- Helpende Zorg \& Welzijn (crebo 92640)

- Dierverzorging 2 (crebo 97330)

TABEL 1 Overzicht mbo-bol niveau 2 beroepsopleidingen geclusterd naar regio die in slechtst scorende 10\%-groep voor percentage werkzaam vallen $(\mathrm{N}=203)$, gediplomeerden van het schooljaar 2012/2013

\begin{tabular}{|c|c|c|c|c|c|c|}
\hline \multirow[t]{2}{*}{ Onderwijssector } & \multirow[t]{2}{*}{ Beroepsopleiding } & \multirow{2}{*}{$\begin{array}{r}\text { Beroeps- } \\
\text { opleidings- } \\
\text { code }\end{array}$} & \multirow{2}{*}{$\begin{array}{r}\text { Werkzaam } \\
(\%)\end{array}$} & \multirow{2}{*}{$\begin{array}{r}\text { Werkzaam } \\
(\%), \\
\text { range }\end{array}$} & \multicolumn{2}{|c|}{ Arbeidsmarktregio's $(\mathrm{N})^{10}$} \\
\hline & & & & & $\begin{array}{l}\text { Behorend tot } \\
\text { onderste 10\% }\end{array}$ & Aangeboden \\
\hline economie & Administratief medewerker & bc003 & 52 & $36-71$ & 21 & 25 \\
\hline groen & Dierverzorging 2 & bc056 & 47 & $44-70$ & 3 & 4 \\
\hline sociaal-cultureel & Facilitaire dienstverlener & bc061 & 64 & $53-84$ & 1 & 4 \\
\hline economie & Financiële beroepen & bc064 & 52 & & 1 & 1 \\
\hline sociaal-cultureel & Helpende Zorg \& Welzijn & bc076 & 63 & $47-100$ & 6 & 34 \\
\hline economie & ICT-medewerker & bc080 & 51 & $42-76$ & 8 & 10 \\
\hline sociaal-cultureel & Kok & bc089 & 63 & $40-93$ & 5 & 10 \\
\hline economie & Particuliere beveiliging & bc165 & 72 & $54-100$ & 1 & 32 \\
\hline gezondheidszorg & Sport- en bewegingsbegeleider & bc199 & 64 & $50-80$ & 1 & 5 \\
\hline techniek & Timmerman & $b c 210$ & 67 & $57-96$ & 1 & 3 \\
\hline economie & Veiligheid en vakmanschap & bc217 & 67 & $55-83$ & 3 & 27 \\
\hline economie & Verkoper & $b c 222$ & 52 & $40-97$ & 14 & 21 \\
\hline \multicolumn{2}{|c|}{ Totaal (alle mbo-bol niveau 2 opleidingen) } & & 65 & $36-100$ & & \\
\hline
\end{tabular}

Bron: DUO, eigen bewerking ROA

Noot: Opleidingen die in meerdere regio's aangeboden worden, zijn meervoudig in de berekening meegenomen.

Deze opleidingen zijn geselecteerd omdat deze in relatief veel arbeidsmarktregio's een laag percentage werkenden onder hun gediplomeerden hebben (zie tabel 1). De hypo-

$\overline{10}$ In totaal worden er 35 arbeidsmarktregio's onderscheiden. 
these is dat de kans groot is dat mbo-scholen voor wat betreft deze opleidingen ervan overtuigd zijn dat die weinig arbeidsmarktperspectief hebben, waardoor de kans groot is dat zij bij deze opleidingen ombuiggesprekken voeren. Tevens is er bij de selectie van opleidingen rekening mee gehouden dat ze binnen verschillende opleidingssectoren vallen.

\section{Verantwoording voor de gehanteerde indicator van arbeidsmarktperspectief}

In de publicatie Macrodoelmatigheid mbo: Inkadering arbeidsmarktperspectief (Cörvers et al., 2014) zijn mogelijke indicatoren voor arbeidsmarktrelevantie van mbo-opleidingen onderzocht. Ze laten zien dat de arbeidsmarktrelevantie van beroepsopleidingen beoordeeld kan worden op basis van twee indicatoren over de intrede van schoolverlaters op de arbeidsmarkt: ten eerste het percentage werkenden (van het CBS) en ten tweede het aandeel gediplomeerden dat onder het eigen niveau werkzaam is (indicator 'onderbenutting van het ROA). De eerste indicator blijkt sterk te correleren met allerlei andere aansluitingsindicatoren, waaronder werkloosheid, spijt van de gevolgde opleiding, en werken buiten richting. Bovendien is deze indicator het gemakkelijkste op instellingsniveau te genereren omdat er gebruik kan worden gemaakt van administratieve gegevens. De indicator onderbenutting geeft in aanvulling hierop nog extra informatie over de aansluiting. Het nadeel van deze indicator is echter dat er op instellingsniveau nog niet voldoende betrouwbare gegevens beschikbaar zijn. Om deze reden is de selectie van opleidingen zoals zojuist beschreven voor onderhavig onderzoek mede gebaseerd op het aandeel werkenden van het totaal aantal gediplomeerden, exclusief de leerlingen die gaan doorleren.

Ondanks de ingestelde zorgplicht en de instelling van beroepsgerichte kwalificaties in 2012, blijven er opleidingen bestaan met relatief weinig arbeidsmarktrelevantie. Recente gegevens over de arbeidsmarktkansen van mbo-gediplomeerden laten zien dat de kans dat jongeren anderhalf jaar na het behalen van het mbo-diploma werkloos zijn sterk varieert tussen opleidingen (ROA, 2013). Terwijl het vijfaarsgemiddelde van het werkloosheidspercentage (periode 2008-2012) van meer dan 100 onderzochte (grote) opleidingen gemiddeld 5 procent bedraagt, kent bijna één op de vijf opleidingen een werkloosheidspercentage van boven de 10 procent en heeft 7 procent van de opleidingen zelfs een werkloosheidspercentage dat hoger is dan 15 procent."

11 Voor een overzicht van arbeidsmarktkenmerken van mbo-gediplomeerden per sector/niveau en opleiding, zie http://roastatistics.maastrichtuniversity.nl/SISOnline/Home.aspx. 
Zoals gesteld worden mbo-scholen in het School-Ex 2.0 Programma gestimuleerd om jongeren die zich aanmelden voor een opleiding met weinig arbeidsmarktperspectief te wijzen op deze beperkte perspectieven. Aan het begin van 2015 ging de Eerste kamer akkoord met het wetsvoorstel 'Macrodoelmatigheid in het beroepsonderwijs.'. Hierdoor zijn mbo-scholen nu ook wettelijk verplicht om vanaf augustus 2015 aankomend studenten goed te informeren over de kwaliteit van opleidingen, het arbeidsmarktperspectief en de inhoud en inrichting van het onderwijs. Hiermee moet de kans dat jongeren kiezen voor een opleiding die niet arbeidsmarktrelevant is, nog verder worden verkleind.

Daarnaast moet de wet 'Macrodoelmatigheid in het beroepsonderwijs' leiden tot een betere spreiding van mbo-opleidingen en tot beroepsonderwijs dat beter aansluit op de vraag vanuit het bedrijfsleven. De verantwoordelijkheid hiervoor wordt primair bij scholen en het (regionale) bedrijfsleven gelegd. De minister krijgt de bevoegdheid om, in het uiterste geval, in te grijpen als partijen hun verantwoordelijkheid niet nemen. Een onafhankelijke adviescommissie onderwijs-arbeidsmarkt moet gaan toezien of mbo-opleidingen goed aansluiten op de regionale arbeidsmarkt.

\section{Verantwoording voor het selecteren van mbo-bol opleidingen}

Voor de voorliggende evaluatie is het van belang opleidingen te selecteren waar naar verwachting de kans het grootst is dat er ombuiggesprekken gevoerd worden. Dit is het geval wanneer het aannemelijk is dat een opleiding weinig arbeidsmarktperspectief heeft. In het kader van arbeidsmarktperspectief is het belangrijk een onderscheid te maken tussen enerzijds de beroepsopleidende leerweg (mbo-bol) en anderzijds de beroepsbegeleidende leerweg (mbo-bbl). De arbeidsmarktkansen van bbl-gediplomeerden zijn namelijk structureel aanzienlijk beter dan voor bol-gediplomeerden. Daarom kan worden gesteld dat het arbeidsmarktperspectief van bbl-opleidingen in de regel beter is dan voor bol-opleidingen.

Bij de bbl-variant werken de studenten drie of vier dagen per week in een erkend leerbedrijf. De rest van de week volgen zij lessen op school. Voordat een student een bblopleiding kan beginnen moet er een arbeidsovereenkomst zijn met een bedrijf. Op deze manier is de vraag van werkgevers direct van invloed op het aanbod van opleidingen en op de instroom van leerlingen in bbl-opleidingen en zijn deze opleidingen per definitie arbeidsmarktrelevant. Het is dan ook niet verrassend dat het aantal beschikbare mbo-bbl plaatsten sterk afhankelijk is van de economische omstandigheden in Nederland (zie tekstbox 3). Omdat bol-studenten bij aanvang van de studie geen arbeidsovereenkomst hoeven te hebben is de arbeidsmarktrelevantie voor deze opleidingen veel minder evident. Bol-studenten brengen wat zij geleerd hebben in de praktijk tijdens stages, die 20 procent tot maximaal 60 procent van de opleiding vormen. De instroom in bol-opleidingen is daardoor niet direct afhankelijk van de vraag van werkgevers. 
Figuur 1 illustreert het verband tussen de economische groei in Nederland en het aanbod aan mbo-bbl plaatsen aan de hand van de instroom van vmbo-gediplomeerden in mbo-niveau 2 opleidingen in de jaren $2009 \mathrm{t} / \mathrm{m}$ 2013. In deze periode is het totaal aantal instromende leerlingen met $16 \%$ gedaald, van iets meer dan 30.000 naar afgerond 25.000. In dezelfde periode daalde de instroom in mbo-bbl opleidingen aanzienlijk sterker dan de instroom in mbo-bol opleidingen (respectievelijk met $40 \%$ en $7 \%$ ). Deze relatief forse daling van het aantal instromers in mbo-bbl is waarschijnlijk grotendeels toe te schrijven aan de recente economische crisis. Een mogelijke structurele daling kan echter niet worden uitgesloten.

FIGUUR 1 Instroom van vmbo-gediplomeerden in mbo-niveau 2 opleidingen, 2009 t/m 2013

BBL

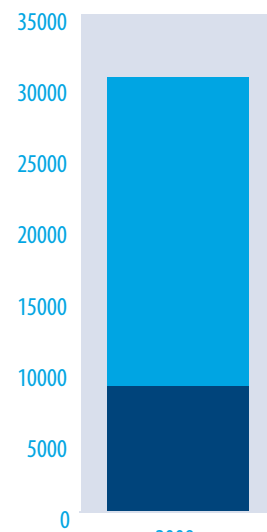

2009

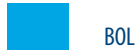

BOL

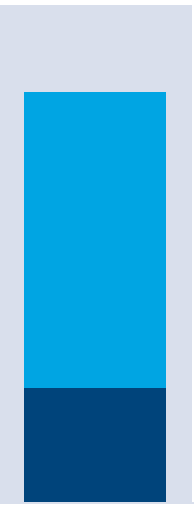

2010

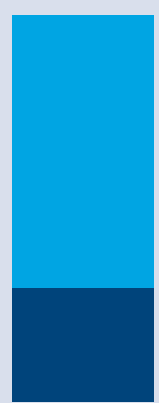

2011

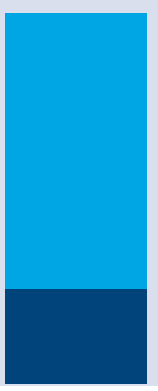

2012

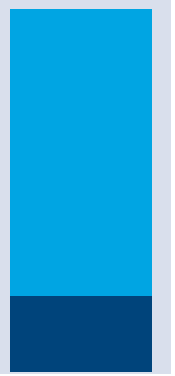

2013

Bron: DUO, eigen bewerking ROA

De absolute en relatieve daling van de instroom in het mbo-bbl is het grootst voor opleidingen in de groene en technische sector (zie tabel 2). Zo daalt in de sector Groen het aandeel dat instroomt in een bbl-opleiding van 35 procent (2009) naar 23 procent (2013) en in de sector Techniek van 59 procent (2009) naar 42 procent (2013). Bij de sectoren Economie en Zorg \& Welzijn was de instroom in mbo-bbl in 2009 al relatief laag, en is deze in 2013 niet veel verder gedaald. In deze sectoren lijkt het aanbod aan leerplekken op mbo-niveau 2 structureel laag te zijn. 
TABEL 2 Instroom van vmbo-gediplomeerden in mbo-niveau 2 opleidingen in 2009 en 2013

\begin{tabular}{|r|r|r|r|r|r|r|r|} 
& Economie & $\begin{array}{r}\text { Administratief } \\
\text { Medewerker }\end{array}$ & $\begin{array}{r}\text { Zorg \& } \\
\text { Welzijn }\end{array}$ & $\begin{array}{r}\text { Helpende } \\
\text { Zorg \& } \\
\text { Welzijn }\end{array}$ & Groen & Dierverzorging 2 & Techniek \\
\hline 2009 & 11.767 & 2.166 & 7.227 & 4.722 & 1.459 & 591 & 9.664 \\
& $(14 \% \mathrm{bbl})$ & $(1 \% \mathrm{bbl})$ & $(11 \% \mathrm{bbl})$ & $(1 \% \mathrm{bbl})$ & $(11 \% \mathrm{bbl})$ & $(11 \% \mathrm{bbl})$ & $(59 \% \mathrm{bbl})$ \\
\hline 2013 & 10.113 & 1.582 & 6.284 & 3.905 & 1.278 & 488 & 7.754 \\
& $(12 \% \mathrm{bbl})$ & $(1 \% \mathrm{bbl})$ & $(8 \% \mathrm{bbl})$ & $(0 \% \mathrm{bbl})$ & $(23 \% \mathrm{bbl})$ & $(7 \% \mathrm{bbl})$ & $(42 \% \mathrm{bbl})$ \\
\hline
\end{tabular}

Bron: DUO, eigen bewerking ROA

De opleidingen Administratief Medewerker en Helpende Zorg \& Welzijn worden structureel vrijwel enkel in bol-variant gevolgd. In beide gevallen startte al aan het begin van de economische crisis slechts $1 \%$ van de vmbo'ers die voor deze opleidingen kozen de bbl-variant. Bij Dierverzorging 2 zien we dat aan het begin van de recente economische crisis $11 \%$ van de vmbo'ers met een bbl-plaats startte terwijl dit in 2013 nog $7 \%$ was.

\section{Verantwoording voor de selectie van mbo-niveau 2 opleidingen}

De kans op werk verschilt niet alleen tussen de leerwegen, maar ook binnen dezelfde leerweg verschilt de kans op werk aanzienlijk tussen niveaus en richtingen. Van mboopleidingen op niveaus $2 \mathrm{t} / \mathrm{m} 4$ is voor gediplomeerden van opleidingen op mbo-niveau 2 de kans op een baan een jaar na afstuderen het kleinst (zie tabel 3). ${ }^{13}$ Van mbo-niveau 2 gediplomeerden kwam 83 procent aan het werk, terwijl dat voor niveaus 2, 3 en 4 samen 86 procent bedroeg. Wanneer we enkel naar bol-gediplomeerden kijken is dit verschil zelfs groter, met 78 procent voor alle mbo-gediplomeerden en 65 procent voor jongeren die een diploma behaalden op mbo-niveau 2 en zich vervolgens aanboden op de arbeidsmarkt. Gediplomeerden van mbo-bol niveau 2 opleidingen in de sector Groen en Techniek vonden het minst vaak hun weg naar de arbeidsmarkt (in beide gevallen 63\%), waarmee deze opleidingsclusters (richting+niveau) op basis van de indicator'kans op werk' te bestempelen zijn als zijnde het minst arbeidsmarktrelevant. ${ }^{14}$

13 Een diploma op mbo-niveau 1 geldt niet als startkwalificatie, wat betekent dat er vanuit kan worden gegaan dat geen enkele mbo-niveau 1 opleiding arbeidsmarktrelevant is. Deze opleidingen worden daarom in dit onderzoek buiten beschouwing gelaten.

14 Dit is opmerkelijk gezien het feit dat het juist deze twee opleidingsclusters zijn die in de bbl-variant het meest 'arbeidsmarktrelevant' zijn wanneer we uitgaan van de indicator 'aandeel werkend'. 
TABEL 3 Aandeel werkenden één jaar na afstuderen, gemiddelde 2009-2011 van 2.431 beroepsopleidingen geclusterd per regio

\begin{tabular}{|l|r|r|r|r|r|}
\hline Opleidingsrichting & niveau & \% bbl & \% werkzaam & \\
\hline Alle richtingen & $2,3,4$ & 53 & 95 & 78 & Totaal (bbl+bol) \\
\hline Alle richtingen & 2 & & & & 86 \\
\hline economie & 2 & 68 & 92 & 65 & 83 \\
\hline gezondheidszorg & 2 & 36 & 90 & 65 & 73 \\
\hline groen & 2 & 30 & $X$ & 69 & 69 \\
\hline sociaal-cultureel & 2 & 41 & 94 & 63 & 85 \\
\hline techniek & 2 & 40 & 88 & 67 & 80 \\
\hline B & 2 & 52 & 93 & 63 & 89 \\
\hline
\end{tabular}

Bron: CBS/SSB, ROA bewerking

Noot: Opleidingen die in meerdere regio's aangeboden worden, zijn meervoudig in de berekening meegenomen.

\subsection{Selectie van interviewrespondenten}

In Hoofdstuk 2 is beschreven dat het voor een succesvolle implementatie van ombuiggesprekken van belang is dat relevante actoren op mbo-scholen bepaalde overtuigingen hebben. "Relevante actoren op mbo-scholen" worden in dit onderzoek gedefinieerd als medewerkers die betrokken zijn bij het aannamebeleid van leerlingen die zich voor het schooljaar 2014/2015 hadden aangemeld voor de mbo-bol niveau 2 beroepsopleiding Administratief Medewerker, Helpende Zorg \& Welzijn, of Dierverzorging 2. Voorbeelden van actoren zijn de opleidingsdirecteur/opleidingsmanager, intaker of docenten van de opleiding.

Om relevante actoren te bereiken is voorafgaand aan de interviews een korte vragenlijst verspreid onder School-Ex contactpersonen op mbo-scholen. Aan deze contactpersonen is gevraagd om de vragenlijst door te sturen naar degene die volgens hen het beste op de hoogte is van het aannamebeleid van leerlingen in het schooljaar 2014/2015 voor de geselecteerde beroepsopleidingen. Voor elk van de drie beroepsopleidingen is een aparte vragenlijst ontworpen. In totaal zijn er 107 vragenlijsten verzonden aan de School-Ex contactpersonen van mbo-scholen en zijn er 72 lijsten ingevuld door de personen die het beste op de hoogte zijn van het aannamebeleid van leerlingen in het schooljaar 2014/2015: 31 vragenlijsten over Administratief Medewerker ${ }^{15}, 31$ vragenlijsten over Helpende Zorg \& Welzijn ${ }^{16}$ en 10 vragenlijsten over Dierverzorging $2^{17}$ (zie bijlage

15 Op verzoek van de desbetreffende scholen hebben twee roc's elk twee vragenlijsten ontvangen, en een roc heeft vier vragenlijsten ontvangen.

16 Op verzoek van de desbetreffende scholen hebben twee roc's elk twee vragenlijsten ontvangen, en een roc heeft vier vragenlijsten ontvangen.

17 Op verzoek van de desbetreffende school heeft één aoc twee vragenlijsten ontvangen. 
2). De functies van de responderende personen varieerden van opleidingsdirecteur of opleidingsmanager tot vakdocent en intaker. ${ }^{18}$

Aan de hand van een enquêtevraag is nogmaals vastgesteld of de respondent op de hoogte is van het aannamebeleid van leerlingen in de betreffende beroepsopleiding in het schooljaar 2014/2015. Indien dit niet het geval bleek te zijn is besloten deze persoon niet te benaderen voor een interview. Responderende personen die aangaven dat er geen activiteiten waren ondernomen om de instroom van het aantal leerlingen in de beroepsopleiding in het schooljaar 2014/2015 te beïnvloeden, kregen de vraag waarom er niet is geprobeerd om het aantal instromende leerlingen te beïnvloeden (meerkeuzevraag). Responderende personen die enkel antwoordden: “Het was niet nodig omdat het aantal aanmeldingen voor deze kwalificatie al laag genoeg was" zijn niet benaderd voor een interview. In dat geval hebben zij immers geen reden om jongeren om te buigen, ook al zouden ze overtuigd zijn van de slechte arbeidsmarktperspectieven van de beroepsopleiding.

Alle overige respondenten van de vragenlijsten werden gezien als potentiële interviewrespondent. In totaal zijn $12 \mathrm{mbo}$-scholen benaderd voor het inplannen van interviews, waarvan er 11 hebben gereageerd. De deelnemende mbo-scholen zijn verspreid over het hele land. Op twee mbo-scholen is zowel over de beroepsopleiding Administratief Medewerker als over Helpende Zorg \& Welzijn gesproken. Op de overige mbo-scholen is over één van de geselecteerde beroepsopleiding gesproken. In totaal zijn er 18 interviews afgenomen op 11 mbo-scholen.

\subsection{Verwerking van de interviews}

In bijlage 3 is de topiclist te vinden die is gebruikt als leidraad voor de semigestructureerde interviews. De onderzoekers hadden de vrijheid om onderwerpen toe te voegen of de topiclist te wijzigen op basis van bevindingen uit eerdere interviews. Op 6 mbo-scholen zijn interviews face-to-face en met 5 mbo-scholen zijn interviews telefonisch afgenomen. De interviews zijn letterlijk getranscribeerd en vervolgens open gecodeerd. Dat wil zeggen dat de kwalitatieve gegevens zijn geanalyseerd zonder dat er van te voren is besloten welke onderwerpen het belangrijkst zijn: een methode die zeer geschikt is voor exploratieve studies. Bij het bespreken van de onderzoeksresultaten zijn letterlijke quotes van respondenten opgenomen. Deze quotes zijn volledig geanonimiseerd, wat betekent dat indien er in de quote een naam van bijvoorbeeld een persoon, regio of school wordt genoemd dit is gewijzigd in "[...]". De referentie bij de quotes bestaat ten eerste uit een nummer van 1 tot 11 (dit dient enkel als doel dat de onderzoekers de quote kunnen herleiden naar de respondent) en daarnaast uit een opleidingsnaam (Administratief Medewerker, Helpende Zorg \& Welzijn of Dierverzorging 2), zodat het duidelijk is over welke opleiding(en) er in dat interview werd(en) gesproken. 


\section{4 \\ RESULTATEN: DE IMPLEMENTATIE VAN OMBUIGGESPREKKEN IN PRAKTIJK}

4.1 De rol van de manier waarop mbo-scholen arbeidsmarktperspectieven bepalen

Voorwaarde 1: Relevante actoren op mbo-scholen zijn ervan overtuigd dat zij een of meerdere mbo-bol niveau 2 opleidingen aanbieden die weinig arbeidsmarktperspectief in de regio hebben, en deze overtuiging is gebaseerd op een betrouwbare indicator.

Voorwaarde 2: Relevante actoren op mbo-scholen zijn ervan overtuigd dat er in de regio mbo-niveau 2 opleidingen worden aangeboden waarvoor de arbeidsmarktperspectieven beter zijn, en deze overtuiging is gebaseerd op een betrouwbare indicator.

Voorwaarde 3. Het (beperkte) arbeidsmarktperspectief van een mbo-bol niveau 2 opleiding is voor relevante actoren op mbo-scholen de doorslaggevende factor bij het bepalen van het aantal leerlingen dat $\mathrm{kan} / \mathrm{mag}$ instromen in die opleiding.

\section{Overtuigingen m.b.t. 'slechte' arbeidsmarktperspectieven, en gehanteerde indicatoren}

Op basis van de gehouden interviews kan vastgesteld worden dat relevante actoren op mbo-scholen ervan overtuigd zijn dat zijéén of meerdere mbo-bol niveau 2 opleidingen aanbieden die weinig arbeidsmarktperspectief in de regio hebben. Op een enkele uitzondering na geven alle respondenten ook aan dat de arbeidsmarktperspectieven voor de drie geselecteerde opleidingen (Administratief Medewerker, Helpende Zorg \& Welzijn en Dierverzorging 2) slecht zijn. Hiermee wordt aan de eerste voorwaarde voor een succesvolle implementatie van ombuiggesprekken voldaan. 
"Niveau 2, daar is eigenlijk gewoon geen beroep meer voor. Dus je ziet in het hele land dat scholen aan het overwegen zijn om die niveau 2 Bedrijfsadministratief Medewerker niet meer aan te bieden omdat er gewoon geen arbeidsrelevantie meer aan zit." (11. Administratief Medewerker (2))

“Maar wij zijn ons terdege bewust van het feit dat er heel weinig banen zijn.” (6. Dierverzorging 2)

"Niveau 2 binnen Zorg \& Welzijn is eigenlijk kansloos - om het maar even kort door de bocht te zeggen richting werkveld. [...] Het is geen opleiding tot werk." (1. Helpende Zorg \& Welzijn)

De uitzondering is een respondent van Dierverzorging 2, die aangeeft dat het arbeidsmarktperspectief van dierverzorging in de veehouderij in zijn regio zeer goed is, waarbij hij zich baseert op gegevens van SBB. In het interview gaf hij wel aan dat er in zijn regio wat betreft arbeidsmarktperspectief een groot verschil is tussen dierverzorging in de veehouderij en dierverzorging in kleindieren. Voor de richting kleindieren is volgens de respondent slechts zeer beperkt arbeidsmarktperspectief in de regio. De betere arbeidsmarktperspectieven voor de richting veehouderij worden bevestigd door een andere respondent van Dierverzorging 2.

"lk praat hier over de opleiding Dierverzorging en die is bij ons dus gericht op het veehouderijbedrijf. We praten heel duidelijk over de agrarische sector, ik praat hier dus niet over de dierverzorging in de kleindieren. Dus dat is dan wel een gigantisch verschil." (4. Dierverzorging 2)

"Met name bij de varkens bij veehouderij niveau 2 is op dit moment best veel vraag naar meisjes die daar in de zeugenstal gaan werken bij de biggetjes zeg maar." (6. Dierverzorging 2)

De meeste respondenten baseren hun beoordeling van de arbeidsmarktperspectieven ten eerste op het aantal beschikbare stageplaatsen. Deze respondenten hebben ervaren dat het voor hun opleiding moeilijk is (geworden) om stageplaatsen te vinden voor alle jongeren die zich aanmelden voor de opleiding, wat wordt gezien als het gevolg van slechte arbeidsmarktperspectieven. Later in deze paragraaf, bij het onderdeel Bepalende factoren voor het aantal leerlingen dat kan/mag instromen: Stages gaan we verder in op de verwachte betrouwbaarheid van het aantal beschikbare stageplaatsen als indicator van het arbeidsmarktperspectief.

Andere genoemde indicatoren voor het arbeidsmarktperspectief van de opleiding is de website kansopwerk.nl, de SBB monitor, Studiewijzer, onderzoeksrapporten, en overleg met bijvoorbeeld een sectorraad, een regionaal platform met betrekking tot de arbeidsmarkt of arbeidsmarktbeleid, of een Bedrijf advies commissie. Op twee mbo-scholen werd door de respondenten aangegeven dat hun school zelf monitort hoeveel van hun gediplomeerden aan het werk komen. 
Hoewel vrijwel alle respondenten aangeven dat de arbeidsmarktperspectieven van hun opleiding slecht zijn, zijn zij er lang niet allemaal van overtuigd dat er in hun regio mbo-niveau 2 opleidingen worden aangeboden waarbij de arbeidsmarktperspectieven (aanzienlijk) beter zijn. Degenen die van mening zijn dat er wel een aantal mbo-niveau 2 opleidingen is met betere arbeidsmarktperspectieven, geven daarbij tegelijkertijd aan dat het aanbod van mbo-niveau 2 opleidingen met betere perspectieven zeer beperkt is, en zich met name in de technische sector bevindt.

“Kun jij één opleiding noemen voor niveau 2 waar er arbeidsperspectief is? lk niet."(1. Helpende Zorg \& Welzijn)

"Dus simpel gezegd komt het erop neer dat van de niveau 2 opleidingen die wij aanbieden, als we dan kijken naar de arbeidsmarkt, er eigenlijk een aantal technische opleidingen nog relevant zijn als het gaat om arbeidsmarktpotentie, maar ook beperkt. Bouw is bijvoorbeeld ook al een enorm probleem, en dat de Facilitair Medewerker een redelijke arbeidsmarktrelevantie heeft, en dat Detailhandel een redelijke arbeidsmarktrelevantie heeft, en de andere eigenlijk niet." (5. Administratief Medewerker en Helpende Zorg \& Welzijn)

"Maar dat geldt ook over de breedte van niveau 2. Het heeft niet alleen met sector te maken, maar ook het arbeidsmarktperspectief van niveau 2 leerlingen neemt steeds meer af. Dat is echt een zorgpunt. Je ziet natuurlijk bij sommigen dat het op groen staat. Maar het wordt steeds moeilijker." (9. Helpende Zorg \& Welzijn) 
TEKSTBOX 4 Ombuigopties: Zijn er mbo-bol niveau 2 opleidingen met goede arbeidsmarktperspectieven?

Om leerlingen succesvol om te buigen van een opleiding met weinig arbeidsmarktperspectief naar een opleiding met 'beter' arbeidsmarktperspectief, is het cruciaal dat er op dat opleidingsniveau opleidingen bestaan met 'goede', of tenminste betere arbeidsmarktperspectieven dan de aanvankelijk gekozen opleiding. Figuur 2 geeft aan de hand van boxplots de verdeling weer van 1.238 beroepsopleidingen (geclusterd naar regio) voor wat betreft het percentage werkenden onder de jongeren die één jaar daarvoor hun diploma hebben behaald. ${ }^{19}$ Hierbij zijn uitsluitend mbo-bol opleidingen meegenomen en is onderscheid gemaakt naar niveau 2 opleidingen enerzijds en niveau 3/4 opleidingen anderzijds. De boxplots zijn eenvoudig te interpreteren het geval wanneer $100 \mathrm{mbo}$-bol opleidingen gesorteerd zouden zijn van het laagste aandeel werkenden tot het hoogste aandeel werkenden. In dat geval geeft de linker lijn tot aan de box de eerste 25 beroepsopleidingen (met het laagste aandeel werkenden) weer. De rechter lijn vanaf de box geeft aan tussen welke scores de laatste 25 beroepsopleidingen (met het hoogste aandeel werkenden) zich bevinden. De lijn in het midden van de box (die de $25^{\mathrm{e}}$ tot de $75^{\mathrm{e}}$ beroepsopleiding weergeeft) staat op de mediane (of: middelste) waarneming. De helft van de beroepsopleidingen heeft een lager aandeel werkenden dan dat percentage, en de andere helft van de opleidingen heeft een hogere score op het aandeel werkenden.

FIGUUR 2 Verdeling van mbo-bol beroepsopleidingen, geclusterd naar regio op de indicator \% werkzaam een jaar na afstuderen (gediplomeerden 2012-2013)

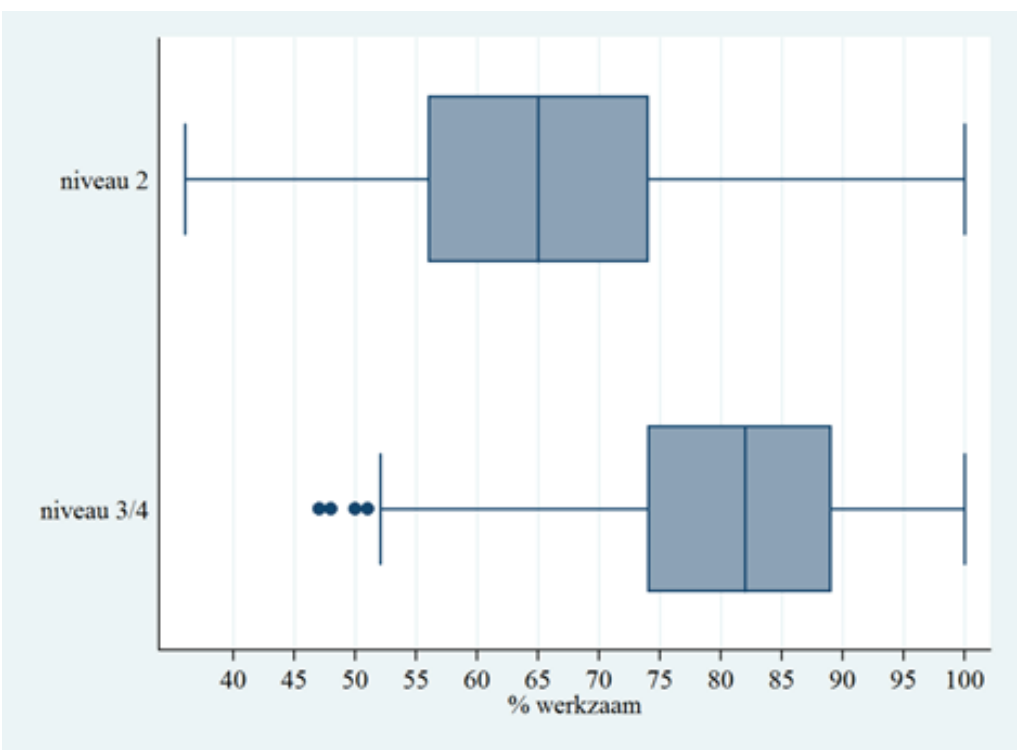

Bron: DUO, eigen bewerking ROA

Noot: Opleidingen die in meerdere regio's aangeboden worden, zijn meervoudig in de berekening meegenomen. 
De lijn in het midden van de boxplot van mbo-bol niveau 2 staat op $65 \%$. Dit betekent dat bij de helft van alle mbo-bol niveau 2 opleidingen meer dan 65 procent van de gediplomeerden werkzaam is. Ter vergelijking: bij de helft van de mbo-bol niveau $3 / 4$ opleidingen is meer dan 82 procent van de gediplomeerden werkzaam. Bij driekwart van de mbo-bol niveau 2 opleidingen is minder dan 74 procent van de gediplomeerden werkzaam. Bij een kwart van de mbo-bol niveau-2-opleidingen is zelfs minder dan 56 procent werkzaam.

Er vanuit gaande dat het arbeidsmarktperspectief van een opleiding 'goed' is als het aandeel werkenden ten minste 80 procent is (zie Cörvers et al., 2014), dan heeft iets meer dan één op de tien beroepsopleidingen op mbo-bol niveau 2 een goed arbeidsmarktperspectief. 0 m mb-bol niveau $3 / 4$ heeft in dat geval meer dan de helft van de opleidingen een goed arbeidsmarktperspectief. $0 \mathrm{p}$ basis hiervan kan voorzichtig worden geconcludeerd dat er weinig beroepsopleidingen op mbo-bol niveau 2 bestaan met 'goede'arbeidsmarktperspectieven. ${ }^{20}$ De mbo-bol niveau 2 opleidingen waarvoor (op arbitraire wijze) kan worden gesteld dat de arbeidsmarktperspectieven 'goed' zijn (ten minste $80 \%$ werkenden) zijn weergegeven in tabel 4 . Het is belangrijk hierbij op te merken dat de gepresenteerde beroepsopleidingen slechts in enkele regio's een hoog percentage werkenden kennen. Afgaande van de landelijke indicator heeft de meerderheid van deze opleidingen minder dan 80 procent werkenden onder hun gediplomeerden.

TABEL 4 Overzicht mbo-bol niveau 2 opleidingen geclusterd naar regio waarbij ten minste $80 \%$ van de gediplomeerden één jaar na afstuderen werkzaam is (2012/2013)

\begin{tabular}{|c|c|c|c|c|c|c|}
\hline Onderwijssector & Beroepsopleiding & Beroeps- & Arbeidsmarl & ktregio's (N) ${ }^{21}$ & Werkzaam ( & \\
\hline techniek & Bedrijfsautotechniek & bc034 & 2 & 2 & $80-100$ & 90 \\
\hline sociaal-cultureel & Facilitaire dienstverlener & bc061 & 2 & 4 & $83-84$ & 64 \\
\hline groen & Groen, grond, infra & bc073 & 1 & 1 & 100 & 88 \\
\hline sociaal-cultureel & Kok & bc089 & 1 & 10 & 90 & 63 \\
\hline sociaal-cultureel & Medewerker bediening/caf,-bar & bc114 & 1 & 3 & 82 & 68 \\
\hline techniek & Metaalbewerken & bc133 & 1 & 2 & 84 & 77 \\
\hline economie & Particuliere beveiliging & bc165 & 4 & 32 & $80-85$ & 72 \\
\hline techniek & Schipper-machinist bep. werkgebied & bc186 & 1 & 1 & 89 & 92 \\
\hline gezondheidszorg & Sport- en bewegingsbegeleider & bc199 & 1 & 5 & 80 & 64 \\
\hline economie & Toezicht en veiligheid & $b c 211$ & 3 & 3 & $82-94$ & 71 \\
\hline economie & Veiligheid en vakmanschap & $b c 217$ & 3 & 27 & $81-83$ & 67 \\
\hline
\end{tabular}

Bron: DUO, eigen bewerking ROA

Noot: Opleidingen die in meerdere regio's aangeboden worden, zijn meervoudig in de berekening meegenomen.

20 Dit is uiteraard afhankelijk van bepaling van een grensbepaling/streefwaarde.

21 In totaal worden er 35 arbeidsmarktregio's onderscheiden. 
Het aantal beschikbare stageplaatsen is voor alle respondenten de voornaamste factor bij het bepalen van de maximale instroom in de betreffende opleiding. Zo lang er stageplaatsen beschikbaar zijn (of kunnen worden gecreëerd) worden leerlingen die zich voor de opleiding hebben aangemeld en aan de toelatingseisen voldoen geplaatst. Wanneer het aantal aanmeldingen groter is dan het aantal beschikbare stageplaatsen zullen leerlingen moeten worden geweigerd, omdat het volgen van een stage noodzakelijk is om het diploma te kunnen behalen.

“Het is gewoon zo, dat we nu op dit moment minder studenten aannemen [...] omdat we minder stageplekken hebben. En je kunt je diploma niet halen als je geen stageplek hebt [gehad]. [...] Er is een één-op-één-relatie met het aantal stageplekken." (1. Helpende Zorg \& Welzijn)

"...de reden daarvoor is omdat de vraag naar de opleiding groter was onder leerlingen dan wij aan stageplaatsen konden bieden. En dus ook aan werkplekken." (11. Helpende Zorg \& Welzijn (2))

"Als je leerlingen aanneemt moet je ook kunnen garanderen - het is een onderdeel van het programma, het is een verplicht onderdeel - moet je ook een stageplek kunnen garanderen. Dat is waar." (1. Administratief Medewerker)

"De uitvoerenden binnen de opleidingen, de BPV-consulenten, weten hoeveel stageplekken zij kunnen inzetten voor deze doelgroep, en mede daarvan wordt het aantal deelnemers bepaald dat kan instromen." (7. Administratief Medewerker en Helpende Zorg \& Welzijn)

Eerder werd al beschreven dat het aantal beschikbare stageplaatsen door de respondenten beschouwd wordt als een belangrijke indicator voor het arbeidsmarktperspectief van de opleiding. Dit betekent dat er bij het bepalen van het aantal instromende leerlingen indirect rekening wordt gehouden met de door de respondenten ingeschatte arbeidsmarktperspectieven. Een belangrijke kanttekening die hierbij moet worden geplaatst is dat meerdere respondenten van Administratief Medewerker en Helpende Zorg \& Welzijn aangeven dat er in het geval van een tekort aan stageplaatsen (d.w.z. het aantal aanmeldingen is groter dan het aantal beschikbare stageplaatsen) wordt geprobeerd om extra stageplaatsen te creëren, om zodoende zo veel mogelijk leerlingen die zich voor de opleiding hebben aangemeld geplaatst te krijgen. De respondenten van Dierverzorging 2 hebben deze mogelijkheid niet genoemd. Een eerste manier waarop extra stageplaatsen worden gecreëerd is door werkgevers te stimuleren om meer stageplaatsen aan te bieden. 
"En dat heeft echt te maken met dat het steeds moeilijker werd om voor al die leerlingen toch een goede stageplek te vinden. En dan veel soebatten, en vooruit, dan kwamen er nog een paar vrij." (11. Helpende Zorg \& Welzijn (2))

“. maar ook stageplekken genereren. Bijvoorbeeld voor niveau 2, daar ben ik heel veel mee bezig op dit moment, om andersoortige stageplekken te vinden. Maar dan gaat het echt op strategisch niveau. Dus dan spreek je met de directeuren, enzovoort. Het gaat niet over individuele plekken, maar echt over substantiële groepen die je kunt plaatsen." (1. Helpende Zorg \& Welzijn)

"Ze krijgen uiteindelijk allemaal een stageplek. Nou ja, dat is te danken aan onze stage coördinator, die echt pusherig [lacht] en drammerig is bij bedrijven." (1. Administratief Medewerker)

Daarnaast zijn er respondenten van Administratief Medewerker en Helpende Zorg \& Welzijn die aangeven dat er stageplaatsen worden gecreëerd waarvoor zij zelf a priori niet verwachten dat die perspectief op (betaald) werk bieden. Voorbeelden hiervan zijn bij Helpende Zorg \& Welzijn stageplaatsen bij een basisschool of een WijkLeerbedrijf. Dit laatste is een relatief nieuw initiatief waarbij deelnemers van mbo-niveau 1 en 2 die een opleiding volgen in zorg en welzijn stage kunnen lopen in de informele zorg in de wijk. De stagiairs helpen bewoners bij allerlei werkzaamheden die zij zelf niet meer kunnen doen, maar waarvoor ze geen thuiszorg of ondersteuning via de gemeente krijgen. ${ }^{22}$ Aangezien het bieden van deze informele zorg momenteel onbetaald / vrijwilligerswerk is, verwachten respondenten niet dat deze stages direct leiden tot betaald werk.

22 Zie voor meer informatie over WijkLeerBedrijven o.a. http://www.calibris.nl/wijkleerbedrijf. 
"...maar wat we ook hebben is de WijkLeerbedrijven. Dat is nu meer een nieuw fenomeen. [...] dat we de studenten stage kunnen laten lopen in de informele zorg. Dat ze niet in de instellingen, maar veel meer wijk gebonden werk bij mensen thuis, boodschappen doen [...] De basisscholen, daar is ook nog wel een grote stageplek. Dat is geen plek waar ze kunnen gaan werken, maar het is wel een stageplek. En daar kunnen ze vaak heel makkelijk terecht." (9. Helpende Zorg \& Welzijn)

“We zijn nu een Wijkleerbedrijf aan het opstarten [...] En dan gaat het over zorg, vooral de informele zorg. En dat is een samenwerking tussen de gemeente, de roc's en de zorginstellingen uit de buurt. Dan moet je denken aan: bij mevrouw De Boer langsgaan om te vragen of we samen boodschappen gaan doen. Of een spelletje, [...] En op die manier kunnen de zorgliefhebbers, zal ik maar zeggen, aan hun trekken komen en hun diploma halen." (1. Helpende Zorg \& Welzijn)

"Nou een alternatief voor de bpv-plaatsen die anders bij werkgevers buiten de school zouden plaatsvinden, dat geeft wat meer ruimte voor studenten om toch nog een plek te vinden waar ze hun examens kunnen laten beoordelen. Of als je kijkt ook bijvoorbeeld dat we veel meer bij basisscholen nu stage laten lopen, omdat ze Zorg \& Welzijn-richting doen, en je ziet bij de basisscholen dat er wel handjes bij kunnen, maar eigenlijk leiden we ze niet op voor de basisschool." (3. Helpende Zorg \& Welzijn)

Bij Administratief Medewerker worden extra stageplaatsen gecreëerd door leerlingen stage te laten lopen binnen de mbo-school, bijvoorbeeld als telefonist/receptionist van een locatie.

"Vorig jaar had ik er eentje, die kon geen stageplek vinden [...] Toen heb ik aan mijn opleidingsmanager gevraagd of het een goed idee zou zijn als hij [...] binnen het gebouw hier aan de overkant een smoelenboek mocht maken. Daarvoor moest hij mensen aanspreken, moest hij afspraken maken. Het is niet helemaal administratief, maar eigenlijk toch ook weer wel. En je moet leren om op tijd te komen, om je aan afspraken te houden, dat boek moest er netjes uit komen te zien." (11. Administratief Medewerker (1))

"Maar uiteindelijk krijgen we ze bijna altijd wel ondergebracht, hebben we wel links en rechts een beetje een escape soms. Hier bij het [... College vinden ze het fijn om een receptionist te hebben, dus dat is altijd een plek die we nog kunnen gebruiken op het moment dat mensen elders niet geplaatst kunnen worden. Wij hebben nog een locatie [...] En daar hebben ze ook vaak iemand bij de receptie nodig. Dus dat zijn dan zo wat uitwijkmogelijkheden mocht iemand geen plaats kunnen vinden." (8. Administratief Medewerker (3))

Wanneer er extra stageplaatsen worden gecreëerd, zal het aantal beschikbare stageplaatsen groter zijn dan de aanvankelijke vraag vanuit de werkgevers, waardoor in dat geval het aantal beschikbare stageplaatsen geen betrouwbare indicator is voor het arbeidsmarktperspectief van de opleiding. Respondenten geven dat ook aan dat 
het voorkomt dat er meer leerlingen tot Administratief Medewerker of Helpende Zorg \& Welzijn worden toegelaten dan waar naar verwachting arbeidsmarktperspectief voor is.

"En dan lukt het vaak nog net wel om ze op stage te krijgen, alleen op het moment dat ze klaar zijn en de arbeidsmarkt op moeten is het nog maar de vraag of ze, als ze hun plek niet over hebben gehouden uit die stage, of ze dan zelfstandig aan een baan komen." (2. Administratief Medewerker)

\section{Bepalende factoren voor het aantal leerlingen dat kan/mag instromen: Doorstroom}

Een andere factor die volgens meerdere respondenten bepalend is voor het aantal leerlingen dat kan/mag instromen in de opleiding, is het aandeel gediplomeerden dat in voorgaande jaren is gaan doorstuderen op mbo-niveau 3. Voor typische 'doorstroomopleidingen' wordt het arbeidsmarktperspectief van de opleiding minder belangrijk gevonden omdat dit perspectief enkel geldt voor een fractie van de gediplomeerden. Als alleen het arbeidsmarktperspectief leidend zou zijn voor het aantal instromende leerlingen, dan zouden volgens deze respondenten veel leerlingen die willen instromen in een 'doorstroomopleiding' geen mogelijkheid krijgen om via mbo-niveau 2 naar niveau 3 door te stromen. Administratief Medewerker en Helpende Zorg \& Welzijn worden door meerdere respondenten typische 'doorstroomopleidingen' genoemd.

“Nou ja, we zijn een doorstroomopleiding. We zijn een tussenstapje, voor veel leerlingen." (1. Administratief Medewerker)

"We quoteren niet. In ieder geval niet voor die opleiding [Administratief Medewerker]. Er zijn andere opleidingen waarbij we dat wel doen, maar voor die opleiding doen we dat niet. 0ok met het oog op het feit dat het ook nog een doorstroom variant kan zijn. En je moet mensen wel kansen blijven bieden." (2. Administratief Medewerker)

"Door al die maatregelen van focus op vakmanschap wordt dat natuurlijk allemaal wat complexer maar ik denk dat het toch wel heel belangrijk is om ook te benadrukken dat naast mensen opleiden voor de arbeidsmarkt wij 0ok die doorstroomfunctie [hebben]." (9. Helpende Zorg \& Welzijn)

"Als wij zien van, we kunnen twee groepen bedienen in de stage maar de arbeidsmarkt wellicht niet... dan zullen we eerder naar de stage-markt dan naar de arbeidsmarkt kijken. 0ok omdat opleidingen gebruikt worden om door te stromen naar de andere opleiding. "(11. Helpende Zorg \& Welzijn (2))

De respondenten zijn zich er wel van bewust dat er door de focus op doorstroom naar mbo-niveau 3 meer leerlingen tot de opleiding worden toelaten dan waar naar verwachting arbeidsmarktperspectief voor is. Ze geven dan ook aan dat ze de leerlingen tijdens 
de opleiding, of in sommige gevallen al bij de intake, stimuleren om na het behalen van het diploma op mbo-niveau 2 door te studeren op mbo-niveau $3 .{ }^{23}$

In tegenstelling tot de respondenten van Administratief Medewerker en Helpende Zorg $\&$ Welzijn, noemen de respondenten van de opleiding Dierverzorging 2 hun opleiding niet een 'doorstroomopleiding'. Voor een grote groep leerlingen dat instroomt in Dierverzorging 2 is mbo-niveau 2 het hoogst haalbare opleidingsniveau. Bij deze opleidingen wordt in het kader van toelatingen dan ook niet gekeken naar doorstroom.

"Nee, er is een enkeling die van niveau 2 doorstroomt naar niveau 3. Over het algemeen zijn de leercapaciteiten van die jongens van dierverzorging natuurlijk niet heel erg hoog."(4. Dierverzorging 2)

"Tegelijkertijd is het wel zo dat wij er hier op de locatie steeds meer achter komen dat het behalen van een startkwalificatie niveau 2 voor een grote groep leerlingen natuurlijk het hoogst haalbare is." (6. Dierverzorging 2)

23 Dit sluit overigens volledig aan bij de doelstellingen van het onderdeel Exitgesprekken van het School-Ex 2.0 Programma. 
Registerdata bevestigen het beeld geschetst door de scholen (zie tabel 5). Onder de gediplomeerden van Administratief Medewerker en Helpende Zorg \& Welzijn, de opleidingen die door meerdere respondenten typische 'doorstroomopleidingen' worden genoemd, begon in de periode 2009/2010 t/m 2012/2013 gemiddeld 69 procent, respectievelijk 65 procent aan een vervolgopleiding. Onder de gediplomeerden van Dierverzorging 2 is de doorstroom wat lager (52\%).

TABEL 5 Percentage mbo-bol niveau 2 gediplomeerden (examenjaar 'og/'10 t/m '12/'13) dat aan een vervolgopleiding is begonnen

\begin{tabular}{|r|r|r|r|r|r|r|r|}
\hline $\begin{array}{r}\text { Econo- } \\
\text { mie }\end{array}$ & $\begin{array}{r}\text { Administratief } \\
\text { Medewerker }\end{array}$ & $\begin{array}{r}\text { Zorg } \\
\text { en } \\
\text { Welzijn }\end{array}$ & $\begin{array}{r}\text { Helpende } \\
\text { Zorg \& } \\
\text { Welzijn }\end{array}$ & Groen & $\begin{array}{r}\text { Dierver- } \\
\text { zorging2 }\end{array}$ & Techniek & Totaal \\
\hline 60 & 69 & 66 & 65 & 46 & 52 & 60 & 62 । \\
\hline
\end{tabular}

Bron: DUO, eigen bewerking ROA

Doorstroom vindt in de regel plaats binnen dezelfde opleidingssector. Zo stroomde tussen de 78 procent (gediplomeerden van sector Groen) en 94 procent (gediplomeerden van de sector Techniek) binnen de eigen sector door. We zien echter ook dat 5 procent van de gediplomeerden van de sector Economie en 8 procent van de gediplomeerden van de sector Groen voor een vervolgopleiding in de sector Techniek koos. Dit geeft aan dat een deel van de jongeren na afronding van een mbo-niveau 2 opleiding bereid is om van sector te wisselen.

Op basis van de School-Ex 2.0 Monitor (ROA, 2013) valt te concluderen dat één op de drie gediplomeerden van het mbo-bol niveau 2 als belangrijkste reden om verder te gaan leren noemt dat de afgeronde opleiding te weinig kansen op het vinden van een baan biedt. Onder de afgestudeerden van de niveau 2 sectoren Economie (36\%) en Zorg \& Welzijn (41\%) ligt dit percentage weliswaar hoger maar wordt nog steeds door minder dan de helft als belangrijkste reden gezien. Het 'leuk vinden' om door te leren en de wens om uiteindelijk in een andere type baan terecht te kunnen komen spelen gezamenlijk bij nog eens bijna 40 procent van de gediplomeerden de hoofdrol om verder te leren. Van de mbo-bol niveau 2 gediplomeerden die niet zijn gaan doorleren geeft een 45 procent aan 'gehinderd' te zijn in het volgen van een vervolgopleiding (bijv. financiële redenen, problemen in de privésfeer/zorg voor kinderen of familie, of niet weten welke vervolgopleiding te kiezen). Naast deze groep 'verhinderden' zijn er onder de gediplomeerden die niet doorstromen naar een vervolgopleiding nog een tweetal relatief grote groepen zichtbaar: de groep jongeren (15\%) voor welke een vervolgopleiding te hoog gegrepen is, en de groep jongeren die liever gaan werken dan verder te leren (20\%). 


\subsection{De verwachte mogelijkheid om jongeren om te buigen}

Voorwaarde 4: Relevante actoren op mbo-scholen zijn ervan overtuigd dat jongeren die zich hebben aangemeld voor Administratief Medewerker, Helpende Zorg \& Welzijn of Dierverzorging 2 overtuigd kunnen worden om hun studiekeuze te wijzigen, en wel dusdanig dat zij in plaats daarvan een mboniveau 2 opleiding met beter arbeidsmarktperspectief kiezen (bijv. in de technische sector).

Voorwaarde 5: Het arbeidsmarktperspectief van een mbo-opleiding is voor jongeren die instromen in het mbo de doorslaggevende factor bij het maken van een studiekeuze.

Voorwaarde 6: Het studiekeuzeproces van jongeren is op zijn vroegst beëindigd op het moment dat ze worden ingeschreven bij een bepaalde opleiding.

Zoals in paragraaf 4.1 al werd beschreven, zijn er volgens de respondenten - met uitzondering van enkele opleidingen in de technische sector - geen of weinig mbo-niveau 2 opleidingen waarvoor de arbeidsmarktperspectieven 'goed' te noemen zijn. Geen enkele respondent is ervan overtuigd dat leerlingen die zich hebben aangemeld voor Administratief Medewerker, Helpende Zorg \& Welzijn of Dierverzorging 2 gestimuleerd kunnen worden om een technische opleiding te gaan volgen. Met name Helpende Zorg $\&$ Welzijn lijkt daarvoor te ver weg te staan van de technische sector. De vraag is welke mbo-niveau 2 opleidingen wel als alternatieven voor de geselecteerde opleidingen worden gezien.

\section{Alternatieve opleidingen om naartoe om te buigen}

Alternatieven mbo-niveau 2 opleidingen voor Helpende Zorg \& Welzijn die worden genoemd zijn "economische of dienstverlenende beroepen" zoals Uiterlijke verzorging, Facilitair medewerker, Horeca, Detailhandel en Verkoper. Uit de interviews kan niet duidelijk worden afgeleid of de respondenten verwachten dat de arbeidsmarktperspectieven van deze alternatieve opleidingen beter zijn dan voor Helpende Zorg \& Welzijn. ${ }^{24}$

24 De opleidingen Verkoper, Facilitair Dienstverlener en Kok komen terug in Tabel 1 (Hoofdstuk 3) waarin mbo-bol niveau 2 opleidingen (geclusterd naar regio) met weinig arbeidsmarktperspectief wordt weergegeven, gebaseerd op het aandeel werkenden onder de gediplomeerden. Facilitair Medewerker en Kok komen - naast Medewerker Bediening café,-bar - echter ook terug in Tabel 4 (paragraaf 4.1, tekstbox 4) welke een overzicht gaf van de mbo-bol niveau 2 opleidingen (geclusterd naar regio) met ten minste 80 procent werkenden. Dat betekent dat Facilitair Medewerker en Kok in sommige regio's weinig arbeidsmarktperspectief hebben, maar in andere regio's juist een goed arbeidsmarktperspectief hebben. 
“En als je voor Zorg \& Welzijn kiest, dan heb je niet vaak als tweede alternatief dat je zegt: “Nou, dan ga ik de techniek wel in". Dan zal het eerder economisch zijn, of een andere dienstverlenende tak waar je naartoe wilt. [...] Kijk, Helpende Zorg \& Welzijn... verwante opleidingen op niveau 2 zijn er bijna niet. In de toekomst hebben we wellicht wat met Facilitair. (11. Helpende Zorg \& Welzijn (2))

“Er komen leerlingen van het vmbo af die gewoon iets met zorg en welzijn willen. Dan kun je wel zeggen: "Ga iets met techniek doen", maar dat werkt echt niet.[...] Dus dat masseren naar andere verwante opleidingen... Het enige wat je nog kunt doen is Uiterlijke Verzorging. En dat doen ze wederzijds. Viterlijke Verzorging wordt ook naar ons gemasseerd. " (1. Helpende Zorg \& Welzijn)

De enige alternatieve mbo-niveau 2 opleiding voor Administratief Medewerker die door de respondenten wordt genoemd is Detailhandel. Daarnaast geven meerdere respondenten aan dat de kwalificaties van de beroepsopleiding Administratief Medewerker (Bedrijfsadministratief Medewerker, Secretarieel Medewerker en Telefonist/Receptionist) niet alle drie even slechte arbeidsmarktperspectieven hebben: het zou met name de kwalificatie Bedrijfsadministratief Medewerker zijn die zeer slechte arbeidsmarktperspectieven heeft, maar de perspectieven voor Secretarieel Medewerker zouden (enigszins) beter zijn.

"Nee, arbeidsperspectief van nul. Secretarieel medewerker; iets beter. Omdat ze altijd wel iemand aan de telefoon voor allerhande klusjes kunnen gebruiken." (1. Administratief Medewerker)

"Binnen de administratieve stageplekken zie je heel erg een verschuiving, echt inderdaad van Bedrijfsadministratief Medewerker naar administratief, de Secretariële Medewerker. Want daar zijn nog echt wel goede plekken voor. Bedrijfsadministratief Medewerker, dat beroep komt eigenlijk ook helemaal te vervallen." (11. Administratief Medewerker (2))

“En ze zijn zelfstandig in staat om een stage te krijgen, c.q. zijn wij in staat ze een stage te bezorgen. En dat, met enige moeite lukt dat nog. Maar dan is ook Secretarieel, Receptionist/Telefoniste makkelijker dan Bedrijfsadministratief Medewerker, omdat gewoon die werkzaamheden er veel minder zijn." (2. Administratief Medewerker)

Jongeren die zich hebben aangemeld voor Bedrijfsadministratief Medewerker worden volgens deze respondenten dan ook wel eens gestimuleerd om in plaats daarvan Secretarieel Medewerker te kiezen. De effectiviteit hiervan is echter niet eenduidig, omdat ondanks dat deze opleidingen inhoudelijk dicht bij elkaar liggen - op verschillende mbo-scholen is het eerste leerjaar voor Bedrijfsadministratief Medewerker en Secretarieel Medewerker volgens de respondenten zelfs exact hetzelfde - het imago van de opleidingen en het type leerlingen dat voor deze opleidingen kiest volgens de respondenten verschillend is. Jongeren die zich aanmelden voor Bedrijfsadministratief Medewerker zouden doorgaans jongens zijn die die opleiding kiezen omdat ze goed 
kunnen rekenen, terwijl Secretarieel Medewerker hoofdzakelijk door meisjes wordt gevolgd met goede communicatieve vaardigheden. Hierdoor zijn niet alle respondenten er volledig van overtuigd dat het mogelijk is om jongeren om te buigen van Bedrijfsadministratief Medewerker naar Secretarieel Medewerker.

“...Administratie, en dan de Boekhouders; dat zijn over het algemeen jongens die hun mond houden. Stille jongens, die goed kunnen rekenen." (1. Administratief Medewerker)

“... als je naar de klassen kijkt, op niveau 2 en niveau 4 is de verdeling man-vrouw bij de Bedrijfsadministratieve tak ongeveer tachtig procent man, twintig procent vrouw. Bij secretariële, is het zeg maar negentig procent [vrouw]. We hebben nu éen jongen in het eerste jaar, en bij niveau 4 hebben we één jongen. Laatst hadden we er ook eentje in het laatste jaar. Hetzelfde geldt voor niveau 2. Het grootste gedeelte daarvan het zal iets minder zijn, zeg maar zeventig-dertig, zeventig procent meisjes, dertig procent jongens." (11. Administratief Medewerker (2))

"Als ik kijk naar de uitstroom, de Boekhoudkundige uitstroom laat ik zeggen. Dat zijn andere leerlingen dan de Secretarieel Medewerker. Een Secretarieel Medewerker [is] communicatiever, en de Boekhoudkundige Medewerkers zijn wat geslotener types." (8. Administratief Medewerker (3))

Een respondent van Dierverzorging 2 geeft aan dat de keuze voor deze opleiding doorgaans zo bewust wordt gemaakt, dat de leerlingen die zich voor deze opleiding aanmelden niet gestimuleerd kunnen worden om een andere mbo-niveau 2 opleiding te gaan volgen. Dat wil zeggen dat de studiekeuze van de jongeren op het moment dat ze zich hebben aangemeld voor die opleiding al volledig vastligt en niet meer veranderd kan worden.

"Die leerlingen die komen voor de veehouderijopleiding zijn zó gefocust op die veehouderijopleiding, dat zij zich niet kunnen voorstellen dat ze een andere opleiding moeten gaan doen." (4. Dierverzorging 2)

\section{Hoe maken jongeren hun studiekeuze?}

Alle respondenten zijn ervan overtuigd dat intrinsieke motivatie de doorslaggevende factor is - en volgens sommigen ook zou moeten zijn - bij het maken van en studiekeuze: jongeren volgen een bepaalde mbo-niveau 2 opleiding, omdat die ze het leukst of meest interessant lijkt, omdat het een opleiding is die 'bij ze past', of omdat ze het zien als een noodzakelijke voorbereiding voor een bepaalde mboniveau 3 oleiding die ze van plan zijn te gaan volgen. Jongeren die zich aanmelden voor een mbo-niveau 2 opleiding zouden zich nog niet bezig houden met de 
arbeidsmarkt. Dit laatste zou (deels) met de leeftijd te maken kunnen hebben.

“Het type dat zich aanmeldt, dat zijn natuurlijk allemaal de basisberoepsgerichte leerweg van het vmbo. [... . Vaak ook nog wel jong en, hoe moet ik het zeggen, wat minder bewust van: wat ga ik nou doen. Vaak ook met allerlei andere dingen bezig nog. Nog helemaal in de puberteit. [...] Die zijn zich minder bewust van, zeg maar, hun loopbaan. Of: "Ik ga nu naar het mbo, ik ga een beroep leren" [...] Het is meer de motivatie: "Ik moet nu eenmaal naar school'"' (8. Administratief Medewerker (4))

"Ik heb niet het idee dat ze daar [kans op werk, de arbeidsmarktperspectieven] mee bezig zijn. Ze hebben toch meer het gevoel dat ze naar school moeten." (11. Administratief Medewerker (1)) 
TEKSTBOX 6 Redenen voor studiekeuze van jongeren: Resultaten uit de evaluatie van het eerste jaar van het School-Ex 2.o Programma

De resultaten uit de interviews bevestigen het beeld dat in de evaluatie van het eerste jaar van het School-Ex 2.0 Programma naar voren kwam: de belangrijkste reden voor jongeren om een bepaalde opleiding te kiezen is dat die opleiding ze het leukst/meest interessant lijkt. Deze kwantitatieve vaststelling is gebaseerd op een vragenlijst onder gediplomeerden van het vmbo (schooljaar 2012/2013) die in het schooljaar 2013/2014 met een mbo-niveau 2 opleiding waren gestart. Hen werd gevraagd waarom ze destijds (toen ze de studiekeuze maakten) voor de huidige mbo-niveau 2 opleiding hadden gekozen (meerdere antwoorden mogelijk). Tabel 6 geeft de zes meest genoemde antwoorden weer, uitgesplitst naar de beroepsopleiding waarin de respondent is ingestroomd.

TABEL 6 Zes meest genoemde redenen voor het volgen van de huidige opleiding (\%)

\begin{tabular}{|c|c|c|c|c|}
\hline (meerkeuze) & $\begin{array}{r}\text { Administratief } \\
\text { Medewerker }\end{array}$ & $\begin{array}{r}\text { Helpende } \\
\text { Zorg \& Welzijn }\end{array}$ & Dierverzorging 2 & $\begin{array}{r}\text { Totaal } \\
\text { niveau } 2\end{array}$ \\
\hline $\begin{array}{l}\text { Deze opleiding lijkt mij het leukst/het } \\
\text { meest interessant }\end{array}$ & 47 & 32 & 54 & 57 \\
\hline $\begin{array}{l}\text { Deze opleiding heb ik nodig als } \\
\text { voorbereiding op een andere opleiding die } \\
\text { ik later wil gaan volgen }\end{array}$ & 47 & 70 & 50 & 39 \\
\hline $\begin{array}{l}\text { De goede kansen op het vinden van werk } \\
\text { met deze opleiding }\end{array}$ & 7 & 12 & 13 & 20 \\
\hline Anders & 14 & 9 & 17 & 14 \\
\hline $\begin{array}{l}\text { Mijn ouders/verzorgers adviseerden mij } \\
\text { om deze opleiding te gaan volgen }\end{array}$ & 5 & 7 & 17 & 8 \\
\hline $\begin{array}{l}\text { Mijn VMBO-school adviseerde mij om deze } \\
\text { opleiding te gaan volgen }\end{array}$ & 11 & 10 & 4 & 7 \\
\hline
\end{tabular}

Bron: Vragenlijst onder VMBO-gediplomeerden van het schooljaar 2012/2013, die in het schooljaar 2013/2014 zijn ingestroomd in een MBO-BOL-opleiding (Evaluatie van het eerste jaar van School-Ex 2.0)

Zowel voor de totale groep vmbo-instromers in mbo-niveau 2 als voor de drie geselecteerde beroepsopleidingen geldt dat de meeste jongeren die opleiding volgen omdat die ze het leukst/meest interessant lijkt of omdat ze die opleiding nodig hebben als voorbereiding op een vervolgopleiding. Aangezien de geselecteerde opleidingen relatief slechte arbeidsmarktperspectieven hebben is het niet verrassend dat bij deze opleidingen "de goede kansen op het vinden van werk met deze opleiding" relatief wat minder vaak als reden voor het volgen van de opleiding wordt genoemd. 0ok hebben de ouders en de vmbo-school enige invloed op de studiekeuze gehad.

\section{Het begin en einde van het studiekeuzeproces}

Eerder in deze paragraaf werd al beschreven dat de respondenten de mogelijkheid in twijfel trekken om jongeren om te buigen naar opleidingen die inhoudelijk weinig overeenkomst hebben met de opleiding waarvoor ze zich hadden aangemeld. Ze gaan 
er vanuit dat jongeren die zich voor de geselecteerde opleidingen hebben aangemeld hooguit hun studiekeuze zullen wijzigen richting een inhoudelijk aanverwante opleiding. Hier ligt de assumptie aan ten grondslag dat de studiekeuze van jongeren grotendeels vastligt op het moment dat ze zich hebben aangemeld voor een bepaalde mbo-opleiding. In andere woorden: het studiekeuzeproces is volgens de respondenten eigenlijk al beëindigd op het moment dat de aanmelding is gedaan en de studiekeuze voor het eerst is vastgelegd. In de periode tussen de aanmelding en de inschrijving zou er daardoor alleen nog zeer beperkte mogelijkheid zijn om de studiekeuze te beïnvloeden.

"Nou dat stuk is, dan kom je weer bij dat LOB-stuk van het vmbo terecht - wat steeds belangrijker aan het worden is want daar moet het eigenlijk gebeuren - dat beroepsbeeld moet daar al ontstaan, want op het moment dat ze bij ons aan het intakegesprek zitten dan hebben ze al een keuze gemaakt eigenlijk he?" (6. Dierverzorging 2)

“ [...] tegelijkertijd zijn we ook veel met de V0-scholen in gesprek gegaan omdat het natuurlijk beter is om in het traject [dat in] een derde of vierde klas VMBO plaatsvindt, om dan al die arbeidsmarktperspectieven goed mee te nemen, dan dat je als ze een keuze hebben gemaakt zegt van: "Nu gaan we je ombuigen"'.' (9. Helpende Zorg \& Welzijn)

Sommige respondenten geven aan dat het mogelijk zou kunnen zijn het studiekeuzeproces te beïnvloeden voordat de aanmelding in het mbo heeft plaatsgevonden. Dit gaat derhalve niet over ombuigen, aangezien dat per definitie ná de aanmelding plaatsvindt.

De respondenten geven aan dat het studiekeuzeproces in de eerste leerjaren van het vmbo in gang zou kunnen worden gezet. Tijdens het studiekeuzeproces zou de uiteindelijke studiekeuze wellicht kunnen worden beïnvloed doordat de interesses van leerlingen voor bepaalde opleidingen beïnvloed zouden kunnen worden. Door jongeren al in een vroeg stadium te stimuleren om na te denken over hun loopbaan en met welke beroepen/opleidingen ze een match zouden kunnen hebben, zou het mogelijk kunnen zijn om interesses voor bepaalde opleidingen 'aan te wakkeren'. De respondenten die aangeven dat het studiekeuzeproces op deze loopbaanoriëntatie in het vmbo beïnvloed zou kunnen worden zien daarin ook een rol weggelegd voor mbo-scholen. De huidige rol hierin is het bieden van informatie over de opleidingen die worden aangeboden, bijvoorbeeld op informatieavonden voor vmbo-leerlingen en/of hun ouders, door middel van flyers, of door vmbo-leerlingen de mogelijkheid te bieden om een of meerdere dagen mee te lopen bij opleidingen (of bijbehorende stages) waarin ze mogelijk geïnteresseerd zijn. 
"En mijn mening is dat het eerste initiatief van vmbo-scholen zou moeten zijn om dat traject op te pakken, om leerlingen voor te bereiden op die overstap, om leerlingen voor te bereiden met de informatie over de vervolgopleiding en daarmee ook over arbeidsrelevantie van het werk wat zij daarmee proberen te bemachtigen. En ik begrijp uit de praktijk dat een vmbo-school dat niet alleen kan, daar heeft hij anderen bij nodig. En daarmee ben ik er voorstander van dat wij als scholen daarbij ondersteunen, en helpen bij het in ieder geval oprakelen, opduikelen van die informatie en wat je daar nou mee zou moeten." (7. Administratief Medewerker en Helpende Zorg \& Welzijn)

"Dat is een traject waarbij leerlingen van het vmbo een middag naar het mbo komen om kennis te maken met: wat houdt de opleiding in op het mbo. En de bedoeling is om de leerlingen daar ook vooral meer praktisch gerichte opdrachten te laten doen. En de leerlingen vanuit het vmbo kunnen zelf de keuze maken van: "Ik kies voor die opleiding of voor die opleiding".' (8. Administratief Medewerker (2))

“Wij hebben drie keer per jaar doe-dagen waarin wij de leerlingen van het vmbo uitnodigen. Dat doen wij in een samenwerkingsverband: "Jullie mogen kiezen om een middag of een morgen mee te lopen met een afdeling waarvan jij denkt dat dat leuk is, of dat nou veehouderij is of loonwerk of voedingsmiddelentechnologie of bloem of groen, maakt niets uit"'.' (4. Dierverzorging 2)

Wat mij betreft zou je al die kinderen gewoon mee moeten nemen naar bedrijven, laat maar zien en voelen. Ik bedoel, als je zelf naar je eigen verleden teruggaat, had je dat misschien ook leuk gevonden." (8. Administratief Medewerker (3))

"Wij laten leerlingen meelopen een dagje. Een dagje is een lang woord, het is een dagdeel, vier lesuren. [...] En we doen de meeloopdag... We koppelen ze aan een leerling in het eerste jaar en daar trekken ze ook die vier uur mee op. En dat betekent ook dat ze in de pauze meegaan naar de kantine. Want als je mij hoort praten over niveau- 2 is alles leuk en alles positief, maar leerlingen hebben een andere invalshoek. (11. Administratief Medewerker (1))

Hoewel respondenten er niet vanuit lijken te gaan dat een match tussen een leerling en een opleiding 'gecreëerd' kan worden, zou het wel mogelijk kunnen zijn om jongeren in te laten zien dat ze met meer opleidingen een match hebben dan ze aanvankelijk wellicht dachten. Hierdoor kan door loopbaanoriëntatie in het vmbo indirect de uiteindelijke opleiding waarvoor de leerlingen zich aanmelden worden beïnvloed. Hierop doorredenerend zou het zo kunnen zijn dat als leerlingen door loopbaanoriëntatie in het vmbo in meer opleidingen geïnteresseerd raken, de kans groter is dat daar ten minste één opleiding tussen zit die 'goed' arbeidsmarktperspectief heeft. 


\subsection{Eventuele negatieve neveneffecten}

Voorwaarde 7: Het stimuleren van leerlingen die zich hebben aangemeld voor een mbo-bol niveau 2 opleiding met weinig arbeidsmarktperspectief om hun studiekeuze te wijzigen, heeft geen negatieve neveneffecten die volgens relevante actoren op mbo-scholen zwaarder wegen dan het positieve effect van betere arbeidsmarktperspectieven voor de toekomstige gediplomeerden.

Indirect houdt deze voorwaarde in dat relevante actoren op mbo-scholen het niet onwenselijk moeten vinden om jongeren die zich voor een mbo-niveau 2 opleiding hebben aangemeld om te buigen. Eerder werd beschreven dat het volgens veel respondenten niet alleen de werkelijkheid is dat jongeren hun studiekeuze baseren op de match tussen zichzelf en de opleiding / het beroep, maar dat dat bovendien wenselijk is. Dit heeft te maken met het negatieve neveneffect van ombuigen die de respondenten voorzien. Meest genoemd is daarbij het verhoogde risico van voortijdig schooluitval. Om het vsv-risico zo veel mogelijk te beperken zou er gestreefd moeten worden naar een optimale match tussen de leerling en de opleiding / het beroep. Hier ligt de assumptie aan ten grondslag dat een goede match samengaat met een relatief sterke intrinsieke motivatie van de leerling om die opleiding te volgen, en dat dit de kans op voortijdige uitval verkleint. Respondenten gaan er daarom vanuit dat het stimuleren van een leerling om een opleiding te volgen die weliswaar beter arbeidsmarktperspectief biedt maar niet per definitie het beste bij de leerling past, het vsv-risico voor die leerling vergroot. Dit leidt ertoe dat zo lang er een duidelijke match is tussen de leerling en de opleiding / het beroep, en er een stageplaats is of gecreëerd kan worden, het de voorkeur heeft om die leerling te plaatsen, ook als het arbeidsmarktperspectief na afstuderen zeer beperkt zal zijn voor die leerling. 
“Nou ja, kijk, zij moeten hun startkwalificatie halen. Dus linksom of rechtsom moeten ze die behalen. En dan maar in de context die hun past, Zorg \& Welzijn. [...] roc's hebben ook een maatschappelijke verantwoordelijkheid. Er komen leerlingen van het vmbo af die gewoon iets met zorg en welzijn willen. [...] Als roc zou je kunnen zeggen van: er is geen werk dus ga maar ergens anders naartoe. Het gevolg daarvan zal zijn, dat ze misschien ergens anders naartoe gaan maar daar uit gaan vallen, want techniek gaat het echt niet worden. Misschien wel, maar dat verwacht ik niet. Dan belandt er dus een hele grote groep op straat. Dat wordt een enorm maatschappelijk probleem, wat bij heel veel mensen in mijn beleving, en ook bij de gemeente, onvoldoende is doorgedrongen."'" (1. Helpende Zorg \& Welzijn)

“Tegelijkertijd is het wel zo dat wij er hier op de locatie steeds meer achter komen dat het behalen van een startkwalificatie niveau 2 voor een grote groep leerlingen natuurlijk het hoogst haalbare is. En of je dat nou met dier of met plant of met groen doet.. ja dat doet er uiteindelijk niet zoveel toe." (6. Dierverzorging 2) ${ }^{\prime \prime}$

"Dat die jongeren en ook die ouders daar gelijk in hebben dat ze dat moeten doen waar hun belangstelling ligt. En dat het dan veel minder om gaat, zeker op deze niveaus, om een bepaald basisniveau te bereiken, waarmee je dus op de arbeidsmarkt kunt functioneren. [Dat] de startkwalificatie veel relevanter [is] dan dat de gekozen opleidingsrichting zo prachtig aansluit op heel veel banen in die vakrichting. Dat is natuurlijk mooi als dat zo is, maar als het niet zo is, dan is het dwangmatige karakter van "ga iets doen waar werk in is" eigenlijk niet de weg waar ik voor kies." (5. Administratief Medewerker en Helpende Zorg \& Welzijn) 
Het aantal voortijdig schoolverlaters laat in de afgelopen jaren een duidelijke daling zien en de doelstelling van maximaal 25.000 nieuwe vsv'ers in 2016 komt heel dichtbij. Het grote merendeel van de vsv'ers is daarbij afkomstig van het mbo (20.402 vsv'ers in het schooljaar 2013/2014), maar 00k daar is in de afgelopen jaren veel bereikt. Mbo-scholen zijn dan ook sterk erop gefocust om voortijdig uitval te voorkomen. Niet alleen omdat ze dat als hun maatschappelijke verantwoordelijkheid zien, maar ook omdat er financiële consequenties aan verbonden zijn. Op basis van het jaarlijks uitgevoerde onderzoek onder voortijdig schoolverlaters (VSV-Monitor 2014) is vast te stellen dat 47 procent van de vsv'ers afkomstig uit het mbo-bol aangeeft dat de wens om van opleiding te wisselen en/of het feit dat de opleiding inhoudelijk niet was wat ze hadden verwacht een (heel) belangrijke rol speelde bij de beslissing om de opleiding voortijdige te verlaten.

De vraag is of dit nog versterkt wordt indien jongeren gestimuleerd worden om hun studiekeuze te wijzigen. $0 \mathrm{~m}$ hierop een antwoord te geven is aan de respondenten van de VSV-Monitor in 2014 de vraag gesteld of de opleiding die ze in het schooljaar 2012-2013 volgden hun eerste opleidingskeuze was. Twee op de drie respondenten gaven aan dat die opleiding die ze voortijdig hadden verlaten hun eerste keuze was. Een derde gaf aan dat de gevolgde opleiding niet hun eerste keuze was. Aan degenen die aangaven dat ze inderdaad van studiekeuze gewisseld waren, werd gevraagd of zij dit destijds deden op basis van een studie-advies. Een op de vier die van studiekeuze gewisseld was deed dit inderdaad op basis van een studie-advies.

TABEL 7 Aandeel vsv-respondenten van het mbo-bol dat wel/niet van studiekeuze is gewisseld en vermeldt dat een aan de studiekeuze gerelateerde reden een (heel) belangrijke rol speelde bij de beslissing om met de opleiding te stoppen

\begin{tabular}{|l|r|r|r|}
\hline & $\begin{array}{r}\text { niet van keuze } \\
\text { gewisseld }\end{array}$ & $\begin{array}{r}\text { van keuze gewisseld zonder } \\
\text { studie-advies }\end{array}$ & $\begin{array}{r}\text { van keuze gewisseld door } \\
\text { studie-advies }\end{array}$ \\
\hline Wilde van opleiding wisselen & 14 & 24 & 24 \\
\hline Opleiding inhoudelijk niet wat ik wilde & 28 & 33 & 41 \\
\hline
\end{tabular}

Meerdere respondenten voegen daaraan toe dat deelnemers van mbo-niveau 2 opleidingen doorgaans een zeer kwetsbare groep vormen die vaak weinig gemotiveerd zijn in het volgen van onderwijs. Deze kenmerken van mbo-niveau 2 deelnemers worden door respondenten in direct verband gebracht met een verhoogd risico van voortijdige schooluitval. Dit betekent dat volgens respondenten ombuigen zou kunnen leiden tot een verhoogde kans op voortijdige uitval, en dat dit risico extra groot is op mbo-niveau 2 deelnemers doorgaans een zeer kwetsbare groep vormen. 
Zijn de vmbo-gediplomeerden die in een mbo-niveau 2 opleiding instromen inderdaad een relatief kwetsbare groep? $0 \mathrm{~m}$ deze vraag nader te analyseren worden in deze tekst box een aantal kenmerken van deze groep jongeren nader besproken en vergeleken met de instromers in een mbo-niveau 3 of 4 opleiding.

Zowel bij de vmbo-instromers in mbo-niveau 2 opleidingen als bij vmbo-instromers in de mbo-niveau $3 / 4$ opleidingen geeft zo' $n 96$ procent van de gediplomeerden van het vmbo (gemeten anderhalf jaar na behalen van het vmbo-diploma, V0-Monitor 2013) aan dat ze bij hun ouders wonen. Daarbij doen zich duidelijke verschillen voor tussen de twee groepen wat betreft de samenstelling van het gezin. Terwijl bij de instromers in een mbo-niveau $3 / 4$ opleiding vier op de vijf respondenten in een tweeoudergezin woont, is dat bij de instromers in een mbo-niveau 2 opleiding bij 'slechts' 70 procent het geval en kent één op de vijf daarbij gescheiden ouders. Daarnaast heeft van de vmbo-gediplomeerden die een mboniveau 2 opleiding startten meer dan 40 procent een vader met maximaal een lager beroepsonderwijs opleidingsniveau, wat zo'n 10 procentpunten hoger is dan bij de jongeren die met een mbo-niveau 3/4 opleiding startten.

Jongeren die vanuit het vmbo met een mbo-niveau 2 opleiding startten geven relatief vaker aan dat ze tijdens hun vmbo-opleiding problemen hebben ervaren. Zo geeft 9 procent van hen aan tijdens de vmbo-opleiding eraan gedacht te hebben om met de opleiding te stoppen (bij jongeren die met een mbo-niveau $3 / 4$ opleiding zijn gestart is dat 3 procent). Vooral school gerelateerde problemen ( $75 \%$ van de respondenten meldt dit) maar ook persoonlijke problemen $(22 \%)$ en de wens om te gaan werken (11\%) melden deze jongeren als oorzaak om eventueel met de vmbo-opleiding te zijn gestopt. Bijna één op de twee vmbo-instromers in mbo-niveau 2 meldt daarnaast met enige regelmaat tijdens de vmboopleiding gespijbeld te hebben en 12 procent vermeldt dat zij door hun vmbo-school tijdelijk geschorst waren. Dat laatste cijfer is daarbij twee keer zo hoog als bij de vmbo-gediplomeerden die met een mboniveau $3 / 4$ opleiding zijn gestart.

Tot slot kan op basis van de School-Ex 2.0 Monitor $(\mathrm{ROA}, 2014)$ vastgesteld worden dat $40 \%$ van de gediplomeerden van het $M B O$ niveau 2 aangeven op een of de andere manier financiële problemen/zorgen te hebben, $12 \%$ is al in contact met justitie of politie gewest, een op de vier kent problemen met de woonsituatie en bijna $30 \%$ kent problemen met familie of ouders. Wat deze aspecten betreft verschillen de gediplomeerden van een $\mathrm{MBO}$ niveau 2 opleiding echter niet significant van jongeren die een $\mathrm{MBO}$ opleiding op niveau $3 / 4$ hebben afgerond. 
"Als ze in een opleiding zitten die niet hun eerste keus is, dan is het gevolg daarvan dat we deze leerlingen, die toch al worstelen met motivationele problemen als het gaat om onderwijs in veel gevallen, nog minder enthousiast zijn over de richting die zij studeren." (5. Administratief Medewerker en Helpende Zorg \& Welzijn)

"Want ik ben zelf ook docent geweest bij niveau 2, en het is echt de leukste groep van de wereld. Je bent blij als je in een hele klas van vierentwintig, of twintig studenten, er drie zijn die een normale thuissituatie hebben." (1. Helpende Zorg \& Welzijn)

“Wij hadden in het verleden wel eens groepen van vijfentwintig, en dat is echt voor niveau 2 te groot. Dat is voor collega's lastig. Dan zie je dat er te weinig individuele aandacht kan zijn, en dat er heel veel studenten gaan uitvallen." (8. Administratief Medewerker (4))

"Maar vaak die basisbehoeften kloppen al niet bij die leerlingen. Het noodzakelijke is niet in huis. Het zijn allemaal [kinderen] van gebroken gezinnen. Of helemaal geen vader en moeder, en zoek het maar uit." (1. Administratief Medewerker)

Een respondent geeft aan dat de kans op werk voor een leerling niet alleen wordt vergroot door een opleiding te volgen met goed arbeidsmarktperspectief, maar dat non-cognitieve vaardigheden zoals zelfverzekerdheid, zelfredzaamheid en flexibiliteit hier ook sterk aan bijdragen. Deze non-cognitieve vaardigheden zouden volgens deze respondent het meest effectief aangeleerd kunnen worden in een opleiding waarmee de leerling een goede match heeft.

“...want een niveau 2 leerling die moet denk ik vooral hebben van zijn persoonlijkheidsontwikkeling.. het op een goede manier zeg maar klaar worden gemaakt voor die arbeidsmarkt, want dat andere stukje dat wordt in de praktijk vaak heel snel zeg maar aangeleerd. Dus wij hebben daar, merken dat we daar een beetje in aan het verschuiven zijn, dat we zoiets hebben van een niveau 2 opleiding dat moet vooral gericht zijn op die persoonlijkheidsontwikkeling - en al die leerlingen hebben recht om dat te proberen te behalen zeg maar - maar dan wel via een kleurtje dan bij hen past. [...]

"Nou ik denk dat als het gaat - waar ik het eerder over had - om je bepaalde vaardigheden, competenties eigen te maken, dat het belangrijker is dat je dat op een pad doet wat je ligt - dat dat een betere manier is om je zeg maar sterker te maken in die competenties [...]." (6. Dierverzorging 2)

Dat het aanleren van non-cognitieve vaardigheden een belangrijke doelstelling is van het mbo wordt door meerdere respondenten genoemd. Het creëren van flexibiliteit en zelfstandigheid lijkt voor hen met name belangrijk te zijn vanwege de recente economische crisis die heeft aangetoond dat de arbeidsmarkt zeer veranderlijk is, en dat flexibiliteit op de arbeidsmarkt van groot belang is voor de kans op werk van de gediplomeerden. Het wordt benadrukt dat het creëren van zelfvertrouwen zeer belangrijk 
is voor MBO-niveau 2 leerlingen, vanwege de kwetsbaarheid van deze groep en hun vergrote risico op voortijdige uitval.

“ Kijk, liefst wil je alles. Liefst wil je dat-ie z'n startkwalificatie haalt, en dat-ie daarmee blijvend aan het werk is, en ook nog blij is met z'n beroepsrichting. Aan de andere kant is de arbeidsmarkt dusdanig veranderd, dat bijna niemand meer werkzaam is in de beroepsrichting waar-ie ooit voor is opgeleid. of in ieder geval heel veel mensen niet. Dus wat je ze ook mee moet geven is een bepaalde mate van flexibiliteit. Van, luister eens, als ik het niet in die richting kan vinden, wat vind ik dan ook leuk, en waar heb ik dan ook de competenties voor om daarin verder te gaan." (2. Administratief Medewerker)

"Ik vind dat een leerling zich moet kunnen redden, zowel in het vervolgonderwijs als op de arbeidsmarkt. Het maakt dan niet uit wat het wordt. Waarbij de leerling, de startende werknemer, de vaardigheden heeft en het zicht heeft op zichzelf en zich weet te redden. Dat op het moment dat hij kiest voor een beroep als, ik noem maar eventjes iets, kapper of als administrateur, of maakt niet uit; stel dat die beroepskansen daar verdwijnen, dat hij de mogelijkheid heeft voor zichzelf om die switch te maken. En dat hij ook zelf kan inzien: voor dat beroep of voor die activiteiten heb ik meer scholing nodig dus dan ga je daar mee aan de slag. Dus dat ze meer zelfsturend worden. Dat vind ik een heel belangrijke."(8. Administratief Medewerker (2))

"Het eerste voor de hand liggende is mensen klaarmaken voor de arbeidsmarkt. [...] Dus eigenlijk die tweeslag: klaarmaken voor de arbeidsmarkt en klaarmaken voor doorstroom naar een vervolgopleiding. Dus dat is het meest voor de hand liggende. En als je het mij vraagt dan denk ik, leerlingen wendbaar maken voor de arbeidsmarkt. Wendbaar maken, dat ze weten dat je ook moet kunnen switchen en hoe je dat dan moet doet. Zelfvertrouwen. En zeker de lagere niveaus. Die hebben altijd gehoord dat ze niks kunnen en dat ze dom zijn. Dus zelfvertrouwen geven. Zorgen dat je heel veel de nadruk legt op de dingen die ze kunnen. Dus het is ook opvoedend in de goede zin van het woord, taak, denk ik." (8. Administratief Medewerker (3))

En wanneer is in jouw ogen een leerling succesvol? "Als hij zelfvertrouwen heeft gekregen en wat zelfbewuster is geworden en in ieder geval een klein beetje een idee heeft van wat hij wilt." [...]"Want een niveau-2'er met alle struikelpartijen die hij heeft gehad om hier te komen, die heeft niet zo'n zelfbeeld van: "Ik mag er zijn en ik kan het goed". Dat zijn er maar heel weinig die dat zijn. Daar moeten ze zich eerst bewust van worden." (11. Administratief Medewerker (1)) 


\section{5 \\ CONCLUSIE, DISCUSSIE EN EEN BLIK OP DE TOEKOMST}

In 2014 is het eerste jaar van het School-Ex 2.0 Programma geëvalueerd (zie Meng, Verhagen, Korthals \& Huijgen, 2014). Uit deze evaluatie van zowel de exit- als de ombuiggesprekken aan mbo-instellingen, bleek dat er onduidelijkheid is over de exacte vorm en inhoud van deze gesprekken en onder welke voorwaarden deze effectief zijn (m.a.w. het gewenste effect hebben). Voor de voorliggende evaluatie van het tweede jaar van het School-Ex 2.o Programma is daarom een verdiepende kwalitatieve evaluatie uitgevoerd, waarbij wordt ingegaan op verschillende deelvragen. Hoe wordt bepaald of een opleiding 'weinig' of 'beter' arbeidsmarktperspectief heeft, en hanteren scholen daarbij dezelfde criteria? Is het vanzelfsprekend dat scholen proberen jongeren om te buigen wanneer zij ervan overtuigd zijn dat een bepaalde opleiding weinig arbeidsmarktperspectief in de regio heeft, of zijn er argumenten om dit (desondanks) niet te doen? Zijn de arbeidsmarktperspectieven van een opleiding doorslaggevend voor de studiekeuze van een vmbo'er, of zijn er andere factoren/personen die een belangrijke(re) rol spelen? Deze vragen zijn onderzocht door middel van semigestructureerde interviews op verschillende mbo-scholen, verspreid over het hele land, welke de beroepsopleidingen Administratief Medewerker, Helpende Zorg \& Welzijn, of Dierverzorging 2 aanboden in het schooljaar 2014/2015..$^{25}$

Het hoofdstuk start met een samenvatting van het onderzoek aan de hand van de zeven randvoorwaarden voor een succesvolle implementatie van ombuigingsgespreken en de uitkomsten van de interviews (paragraaf 5.1 tot en met 5.3). In paragraaf 5.4 werpen we een blik op de nabije toekomst en staan we stil bij de geplande herziening van de kwalificatiedossiers in het mbo. Tot slot van dit hoofdstuk (paragraaf 5.5) volgt een beschouwende discussie van de resultaten, waarbij we deze plaatsen binnen een beleidskader.

25 Deze opleidingen zijn als case studies geselecteerd omdat deze in relatief veel arbeidsmarktregio's een laag percentage werkenden onder hun gediplomeerden hebben. De hypo:hese is dat de kans groot is dat mboscholen voor wat betreft deze opleidingen ervan overtuigd zijn dat die weinig arbeidsmarktperspectief hebben, waardoor de kans groot is dat zij bij deze opleidingen ombuiggesprekken voeren. Tevens is er bij de selectie van opleidingen rekening mee gehouden dat ze binnen verschillende opleidingssectoren vallen. 


\subsection{De rol van de manier waarop mbo-scholen arbeidsmarktperspectieven bepalen}

Voorwaarde 1. Relevante actoren op mbo-scholen zijn ervan overtuigd dat zij één of meerdere mbo-bol niveau 2 opleidingen aanbieden die weinig arbeidsmarktperspectief in de regio hebben, en deze overtuiging is gebaseerd op een betrouwbare indicator.

Relevante actoren op mbo-scholen zijn ervan overtuigd dat de beroepsopleidingen Administratief Medewerker, Helpende Zorg \& Welzijn en Dierverzorging 2 weinig arbeidsmarktperspectief hebben in hun regio. Hiermee wordt aan het eerste deel van deze voorwaarde voldaan. De beoordeling van de arbeidsmarktperspectieven wordt doorgaans gebaseerd op het aantal beschikbare stageplaatsen. Het is echter de vraag of het aantal beschikbare stageplaatsen een betrouwbare indicator is voor het arbeidsmarktperspectief van de opleiding, zeker in het geval er extra stageplaatsen worden gecreeerd (zie voorwaarde 3).

Voorwaarde 2. Relevante actoren op mbo-scholen zijn ervan overtuigd dat er in de regio mbo-niveau 2 opleidingen worden aangeboden waarvoor de arbeidsmarktperspectieven beter zijn, en deze overtuiging is gebaseerd op een betrouwbare indicator.

Aan deze voorwaarde wordt niet op alle mbo-scholen voldaan. Niet alle respondenten zijn er van overtuigd dat er in hun regio mbo-niveau 2 opleidingen worden aangeboden waarbij de arbeidsmarktperspectieven 'beter' zijn, laat staan 'goed'. Dit wordt bevestigd door registerdata van DUO gekoppeld aan CBS data: slechts iets meer dan één op de tien mbo-bol niveau 2 opleidingen (geclusterd naar regio) heeft een 'goed' arbeidsmarktperspectief (ten minste $80 \%$ werkenden). Bovendien hebben de opleidingen die wél (gemiddeld) 80 procent of hoger scoren op het aandeel werkenden slechts in een beperkt aantal regio's goede perspectieven. Bij de helft van de mbo-bol niveau 2 opleidingen is minder dan 65 procent van de gediplomeerden een jaar na afstuderen werkzaam.

Voorwaarde 3. Het (beperkte) arbeidsmarktperspectief van een mbo-bol niveau 2 opleiding is voor relevante actoren op mbo-scholen de doorslaggevende factor bij het bepalen van het aantal leerlingen dat $\mathrm{kan} / \mathrm{mag}$ instromen in die opleiding.

Het aantal beschikbare stageplaatsen is voor alle respondenten de voornaamste factor bij het bepalen van de maximale instroom in de betreffende opleiding. Dat betekent dat er indirect aan de derde voorwaarde wordt voldaan, mits het aantal beschikbare stage- 
plaatsen een betrouwbare indicator is van het arbeidsmarktperspectief van een opleiding. Dit laatste is echter niet het geval wanneer er extra stageplaatsen worden gecreeerd, wat aan meerdere ROC's het geval blijkt te zijn voor wat betreft de opleidingen Administratief Medewerker en Helpende Zorg \& Welzijn. Bovendien is het (beperkte) arbeidsmarktperspectief van een opleiding niet leidend voor het bepalen van de instroom wanneer de opleiding door relevante actoren gezien wordt als een typische 'doorstroomopleiding'. In dat geval geldt het (beperkte) arbeidsmarktperspectief namelijk voor een relatief kleine groep.

\subsection{De verwachte mogelijkheid van ombuigen}

Voorwaarde 4. Relevante actoren op mbo-scholen zijn ervan overtuigd dat jongeren die zich hebben aangemeld voor een mbo-bol niveau 2 opleiding met weinig arbeidsmarktperspectief (bijv. Administratief Medewerker, Helpende Zorg \& Welzijn, of Dierverzorging 2) overtuigd kunnen worden om hun studiekeuze te wijzigen, en wel dusdanig dat zij in plaats daarvan een mbo-niveau 2 opleiding met beter arbeidsmarktperspectief kiezen en afronden (bijv. in de technische sector).

Uit de interviews is af te leiden dat in de regel niet aan deze voorwaarde wordt voldaan. Ten eerste zijn er, zoals bij voorwaarde 2 al werd geconcludeerd, zeer weinig mbo-niveau 2 opleidingen waarvoor de arbeidsmarktperspectieven 'beter' of 'goed' te noemen zijn. Bovendien is geen enkele respondent ervan overtuigd dat jongeren die zich hebben aangemeld voor Administratief Medewerker, Helpende Zorg \& Welzijn, of Dierverzorging 2 gestimuleerd kunnen worden om een technische opleiding te gaan volgen. Het is niet duidelijk of de mbo-niveau 2 opleidingen die wel als alternatief voor de geselecteerde opleidingen worden gezien, betere arbeidsmarktperspectieven in de regio hebben.

Voorwaarde 5. Het arbeidsmarktperspectief van een mbo-opleiding is voor jongeren die willen instromen in het mbo-bol niveau 2 de doorslaggevende factor bij het maken van een studiekeuze.

Aan deze voorwaarde lijkt niet te worden voldaan. Alle respondenten zijn ervan overtuigd dat intrinsieke motivatie de doorslaggevende factor is - en volgens sommigen ook zou moeten zijn - bij het maken van een studiekeuze: jongeren volgen een bepaalde mbo-niveau 2 opleiding omdat die ze het leukst of meest interessant lijkt, omdat het een opleiding is die 'bij ze past', of omdat ze het zien als een noodzakelijke voorbereiding voor een bepaalde mbo-niveau 3 opleiding die ze van plan zijn te gaan volgen. Dit wordt bevestigd door resultaten van een enquête onder vmbo-gediplomeerden van het schooljaar 2012/2013 die in het schooljaar 2013/2014 instroomden in een mbo-niveau 2 opleiding. 
Voorwaarde 6. Het studiekeuzeproces van jongeren is op zijn vroegst beëindigd op het moment dat ze worden ingeschreven bij een bepaalde opleiding.

De respondenten zijn er niet van overtuigd dat aan deze voorwaarde kan worden voldaan. Zij zijn ervan overtuigd dat het studiekeuzeproces is afgerond op het moment dat jongeren zich voor een bepaalde opleiding hebben aangemeld. In de periode tussen de aanmelding en de inschrijving zou er daardoor alleen nog zeer beperkte mogelijkheid zijn om de studiekeuze te beïnvloeden. Sommige respondenten geven aan dat het studiekeuzeproces mogelijk kan worden beïnvloed voordat de aanmelding in het mbo heeft plaatsgevonden. Dit gaat derhalve niet over ombuigen, aangezien dit per definitie ná de aanmelding plaatsvindt. Door jongeren al in een vroeg stadium te stimuleren om na te denken over hun loopbaan en met welke beroepen/opleidingen ze een match zouden kunnen hebben, zou het mogelijk kunnen zijn om interesses voor bepaalde opleidingen 'aan te wakkeren'.

\subsection{Eventuele negatieve neveneffecten van ombuigen}

Voorwaarde 7. Het stimuleren van leerlingen die zich hebben aangemeld voor een mbo-bol niveau 2 opleiding met weinig arbeidsmarktperspectief om hun studiekeuze te wijzigen heeft geen negatieve neveneffecten die volgens relevante actoren op mbo-scholen zwaarder wegen dan het positieve effect van betere arbeidsmarktperspectieven voor de toekomstige gediplomeerden.

Respondenten gaan er vanuit dat het stimuleren van een leerling om een opleiding te volgen die weliswaar beter arbeidsmarktperspectief biedt maar niet per definitie het beste bij de leerling past, het vsv-risico voor die leerling vergroot. Dit risico zou extra groot zijn voor mbo-niveau 2 deelnemers omdat dat doorgaans een zeer kwetsbare groep is. Het voorziene negatieve neveneffect van een toename van het aantal vsv'ers wordt dusdanig onwenselijk gevonden, dat het ertoe leidt dat het de voorkeur heeft om die leerling te plaatsen bij een opleiding die aansluit bij de interesses en capaciteiten van de leerling, ook als het arbeidsmarktperspectief na afstuderen (zeer) beperkt zal.

\subsection{Een blik op de nabije toekomst: Herziening Kwalificatiedossiers mbo}

Dit onderzoek richt zich op drie beroepsopleidingen die in het schooljaar 2014/2015 werden aangeboden op mbo-niveau 2. Ten behoeve van toekomstig onderzoek en de implementatie van de onderzoeksresultaten is het belangrijk om onder de aandacht te brengen dat deze beroepsopleidingen met ingang van het schooljaar 2015/2016 binnen een nieuwe kwalificatiestructuur vallen. Scholen mogen met ingang van het schooljaar 2015/2016 starten met opleidingen op basis van herziene kwalificatiedossiers, en met 
ingang van het schooljaar 2016/2017 zijn scholen verplicht opleidingen conform de herziene dossiers aan te bieden. Tekstbox 9 presenteert een korte samenvatting van de belangrijkste punten van de herziening van de kwalificatiedossiers. In het kader van het voorliggende rapport zijn vooral de punten 1. (stevige opbouw) en 2. (verder clusteren) relevant.

TEKSTBOX 9 Herziening kwalificatiedossiers ${ }^{26}$

\section{Stevige opbouw}

De mbo-opleiding bestaat straks uit drie delen: een basis-, profiel- en keuzedeel. De basis bevat informatie die voor een groep beroepen nodig is. De verschillen tussen die beroepen zijn uitgewerkt in het profiel. Het keuzedeel is aanvullend aan het kwalificatiedossier en is een verrijking van het diploma. Met deze nieuwe opbouw wordt de samenhang in de dossiers duidelijker.

2. Verder clusteren

Een aantal dossiers wordt op een andere manier geclusterd. Voor scholen levert dit houvast op voor een doelmatige opleidingsorganisatie en voor bedrijven beter inzetbare arbeidskrachten.

3. Afspraken over examinering

Aan welke eisen een mbo'er moet voldoen om een diploma te behalen, wordt beter beschreven. Er wordt bijvoorbeeld duidelijker beschreven welke kennis en vaardigheden nodig zijn.

4. Terug naar de essentie

Kwalificatiedossiers worden dunner en overzichtelijker.

TABEL 8 Nieuwe kwalificatiedossiers van de opleidingen die in dit onderzoek centraal stonden, inclusief het aandeel werkenden onder gediplomeerden van het schooljaar $2012 / 2013$

\begin{tabular}{|llll}
\hline Ondersteunende administratieve beroepen & Medewerker (financiële) administratie & 2 & $52^{26} / 52^{27}$ \\
& Medewerker secretariaat en receptie & 2 & $52^{28}$ \\
\hline Dienstverlening & Helpende Zorg \& Welzijn & $\mathbf{2}$ & 63 \\
& Medewerker sport en recreatie & 2 & $64^{29}$ \\
& Medewerker facilitaire dienstverlening & 2 & 64 \\
\hline Dierverzorging & Bedrijfleider dierverzorging & & \\
& Vakbekwaam medewerker dierverzorging & 3 & $43^{30}$ \\
& Proefdierverzorger & 3 & $\mathrm{X}$ \\
& Medewerker dierverzorging & 2 & 47 \\
& Dierenartsassistent paraveterinair & 4 & 47
\end{tabular}

Bron: kwalificatiesmbo.nl en DUO, eigen bewerking ROA

26 Zie voor meer informatie www.kwalificatiesmbo.nl.

27 Financiële beroepen.

28 Administratief Medewerker.

29 Administratief Medewerker.

30 sport-en bewegingsbegeleider.

31 Gespecialiseerde dierverzorging gezelschapsdieren. 
In de nieuwe kwalificatiestructuur wordt een aantal inhoudelijk aanverwante opleidingen (kwalificaties) geclusterd in één kwalificatiedossier. Deze verwante kwalificaties worden niet noodzakelijkerwijs allemaal op hetzelfde mbo-niveau aangeboden. Met de invoering van de nieuwe kwalificatiedossiers is het mogelijk om leerlingen in een kwalificatiedossier in te schrijven zonder dat daarbij direct een aanmelding voor een van de onderliggende kwalificaties plaatsvindt.

Naast het basis- en profieldeel kunnen in de nieuwe kwalificatiestructuur ook verdiepende, verbredende of op doorstroom-gerichte keuzedelen worden gevolgd. In het kader van ombuigen zijn met name de verbredende en op doorstroom-gerichte keuzedelen van belang. Verbredende keuzedelen zijn gericht op een element van een andere kwalificatie binnen hetzelfde kwalificatiedossier. Het is in de nieuwe kwalificatiestructuur niet mogelijk om een verbredend keuzedeel van een ander kwalificatiedossier te volgen. Het volgen van een op doorstroom-gericht keuzedeel biedt jongeren de mogelijkheid om met een vervolgopleiding kennis laten maken en de noodzakelijke duur van de vervolgopleiding inkorten. Zo kunnen in een keuzedeel gericht op doorstroom bijvoorbeeld al taal en rekenvaardigheden aangeleerd worden die op een hoger mboniveau vereist zijn.

Respondenten bleken ervan overtuigd zijn dat jongeren in de periode na aanmelding nog hooguit gestimuleerd kunnen worden om hun studiekeuze te wijzigen richting een opleiding die inhoudelijk verwant is aan de opleiding waarvoor ze zich hadden aangemeld, omdat het studiekeuzeproces is afgerond nadat de aanmelding is voltooid. De nieuwe kwalificatiestructuur biedt mbo-scholen de mogelijkheid om jongeren ná aanmelding bij een kwalificatiedossier te stimuleren om zich te specialiseren in de kwalificatie binnen het kwalificatiedossier waarvoor het arbeidsmarktperspectief het beste is. Dit betekent dat het met de invoering van de nieuwe kwalificatiedossiers naar verwachting eenvoudiger zal worden om jongeren te stimuleren om een aanverwante opleiding te gaan volgen, omdat die opleiding waarschijnlijk binnen hetzelfde kwalificatiedossier valt. Zoals in het rapport al werd beschreven, is het aandeel mbo-niveau 2 opleidingen met weinig arbeidsmarktperspectief echter dusdanig hoog, en het aandeel met 'goed' perspectief (ten minste $80 \%$ werkenden onder de recent gediplomeerden) dusdanig laag, dat het de vraag is of er binnen één kwalificatiedossier mbo-niveau 2 kwalificaties worden aangeboden waarvoor het arbeidsmarktperspectief 'beter' is.

Van de opleidingen die in dit onderzoek centraal staan, wordt enkel de kwalificatiestructuur van Helpende Zorg \& Welzijn gewijzigd (zie tabel 8). De huidige opleiding Administratief Medewerker bestaat immers al uit drie kwalificaties, namelijk 1) Bedrijfsadministratief Medewerker (vergelijkbaar met de nieuwe kwalificatie Medewerker (financiële) Administratie), 2) Secretarieel Medewerker en 3) Telefonisch/ Receptionist (samen vergelijkbaar met de nieuwe kwalificatie Medewerker Secretariaat en Receptie). Hierdoor is Administratief Medewerker in de nieuwe kwalificatiestructuur niet verbreed. Het nieuwe kwalificatiedossier Dierverzorging bevat slechts één kwali- 
ficatie op mbo-niveau 2, waardoor hier alleen een mogelijkheid tot stapelen wordt geboden en er geen horizontale verbreding kan plaatsvinden.

Jongeren die voorheen Helpende Zorg \& Welzijn studeerden, melden zich in de nieuwe kwalificatiestructuur aan voor Dienstverlening, en beslissen pas later of ze opgaan voor het diploma van Helpende Zorg \& Welzijn, Medewerker Sport en Recreatie of Medewerker Facilitaire Dienstverlening. In tabel 8 is echter te zien dat de arbeidsmarktperspectieven voor deze overige twee kwalificaties op landelijk niveau momenteel niet beter zijn dan voor de 'oude' kwalificatie Helpende Zorg \& Welzijn.

Tijdens de interviews kwam naar voren dat meerdere respondenten vrezen dat met de invoeren van het Cascademodel - waarin de bekostiging van een mbo-student afneemt naar mate de verblijfsduur toeneemt ${ }^{32}$ - het moeilijker wordt om jongeren mbo-opleidingen te laten 'stapelen' en via mbo-niveau 2 door te stromen naar hogere opleidingsniveaus.

"Dat stapelen, dat mag niet meer." (1. Administratief Medewerker)

Want u heeft een paar keer aangegeven dat er toch ook wel een groep is die doorstroomt naar niveau 3, hoe combineert zich dat met de invoering van het cascademodel?"Niet. Wij vinden dat ook heel erg. We vinden het een teloorgang van het onderwijs, moeten we nu even ons hart uitstorten? Nee, dat is verschrikkelijk natuurlijk. We hebben leerlingen die soms laat starten, die gemotiveerd raken als ze een beroepsopleiding doen, en het Cascademodel... Ja het roc betaalt de prijs, om het zo maar eens te noemen. Maar wij willen de leerlingen dat niet onthouden. Dat is nog gelukkig het beleid van onze school, dat doorstroom wel mogelijk is. Het mag namelijk ook officieel geen reden zijn om iemand af te wijzen, maar het wordt wel een groot probleem. (3. Helpende Zorg \& Welzijn)

Het aanbieden van keuzedelen die gericht zijn op doorstroom zouden de stapeltrajecten moeten verkorten. Dit zou wellicht de door de respondenten voorziene problemen rondom de invoering van het Cascademodel kunnen 'verzachten'.

\subsection{Beschouwende discussie}

Op basis van de resultaten van dit onderzoek is een viertal spanningsvelden geïdentificeerd, welke in deze paragraaf worden toegelicht.

Spanningsveld 1: Mbo-bol diploma niveau 2: basis voor arbeidsmarkt en basis voor vervolgonderwijs

32 Zie bijvoorbeeld www.mbo15.nl/node/328 voor meer informatie over het Cascademodel. 
Het eerste spanningsveld dat beleidsmatig van groot belang is, is het spanningsveld dat ontstaat door het gegeven dat een mbo-bol niveau 2 diploma niet per definitie het einde van de onderwijscarrière is. ${ }^{33}$ Naast een startkwalificatie voor de arbeidsmarkt moeten mbo-bol opleidingen op niveau 2 namelijk een basiskwalificatie bieden voor vervolgonderwijs: 62 procent van de leerlingen start immers een vervolgopleiding. In principe wordt binnen het huidige School-Ex 2.0 programma met beide kwalificaties rekening gehouden (exitgesprekken om jongeren te stimuleren na behalen van een basiskwalificatie verder te gaan leren; ombuigingsgesprekken om jongeren te stimuleren om een opleiding te kiezen die voldoende arbeidsmarktperspectief biedt). Voor opleidingen die hoofdzakelijk een doorstroomfunctie hebben, wat relatief vaak het geval is bij mbo-bol opleidingen op niveau 2, geldt dat een sterk eenzijdige beoordeling op arbeidsmarkrelevantie niet kan volstaan. Hiernaast zou op zijn minst een gelijkwaardige beoordeling op basis van 'vervolgonderwijsrelevantie' moeten plaatsvinden.

'Vervolgonderwijsrelevantie' is daarmee idealiter meer dan een relatief hoog percentage leerlingen dat doorstroomt naar een vervolgopleiding. Van even groot belang is dat jongeren de vervolgstudie(s) met succes afronden en dankzij het (de) diploma(s) van de vervolgstudie(s) een succesvolle transitie naar de arbeidsmarkt kunnen maken. Met andere woorden moet met een stijgend onderwijsniveau de focus deels verschuiven van vervolgonderwijsrelevantie naar arbeidsmarktrelevantie. Wanneer men de macrodoelmatigheid van opleidingen wil toetsen, zal daarom gedifferentieerd moeten worden naar verschillende opleidingsniveaus, waarbij de vervolgonderwijsrelevantie en arbeidsmarktrelevantie ieder een afzonderlijk gewicht krijgen. Het is daarbij belangrijk om de doorstroomfunctie van opleidingen in acht te nemen:

- Bij mbo opleidingen op niveau 2 dient de opbouw van de opleiding zodanig te zijn dat, zonder afbreuk te doen aan de arbeidsmarktkansen van niet-doorstromers, de leerlingen kunnen doorstromen naar vervolgopleidingen die voldoende arbeidsmarktrelevant zijn.

- Voor mbo opleidingen op niveau 2 - met name de opleidingen met een hoog doorstroompercentage - dienen ombuigingsgesprekken te worden gevoerd op basis van een combinatie van de arbeidsmarktrelevantie van deze niveau 2 opleiding en de arbeidsmarktrelevantie van potentiële vervolgopleidingen op niveau 3 en 4.

In de opzet van het School-Ex 2.o programma is wat de ombuigingsgesprekken betreft ten onrechte noch rekening gehouden met het belang van vervolgonderwijsrelevantie van de opleiding, noch met de arbeidsmarktrelevantie van de potentiële vervolgopleidingen. Eventuele vervolginitiatieven die erop gericht zijn jongeren te stimuleren in het kiezen van een opleiding met een hoge arbeidsmarktrelevantie dienen hiermee rekening te houden.

33 Dit geldt natuurlijk ook voor mbo-bbl opleidingen. Echter, het voorliggende rapport richtte zich op opleidingen in de mbo-bol, aangezien mbo-bbl opleidingen per definitie arbeidsmarktrelevant zijn. 
Voortbordurend op bovengenoemde conclusies is het interessant om na te denken over een verbreding wat de opzet van mbo-bol opleidingen op niveau 2 in het algemeen, en specifiek voor opleidingen die structureel slechte arbeidsmarktperspectieven kennen. ${ }^{34}$ Hierbij moet 'breed' worden geïnterpreteerd zowel in termen van vakinhoudelijke als generieke vaardigheden. Dergelijke brede opleidingen dienen enerzijds een basis te bieden voor verschillende (arbeidsmarktrelevante) vervolgopleidingen en anderzijds te leiden tot een flexibele inzet van de jongeren op de arbeidsmarkt. Het tweede aspect is vooral van belang voor de jongeren die niet doorstromen naar een opleiding op een hoger niveau. De huidige ontwikkelingen op de arbeidsmarkt (polarisering, flexibilisering en digitalisering) maken dat jongeren over een zekere flexibiliteit moeten beschikken om zich te kunnen handhaven op een snel veranderende arbeidsmarkt. Hoewel bredere opleidingen jongeren wendbaar maken op de arbeidsmarkt, blijkt deels uit eerder onderzoek (zie bijvoorbeeld ROA, 2014) dat specifiekere opleidingen vaak in termen van arbeidsmarktsucces op de korte termijn beter scoren en het belang van flexibiliteit vooral toeneemt in het verdere verloop van de arbeidsmarktcarrière. Of dit echter ook specifiek geldt voor mbo-bol niveau 2 opleidingen is in de regel niet nader onderzocht. Des te meer is het van groot belang dat het opzetten van experimenten met bredere mbo-bol niveau 2 opleidingen nauw gekoppeld wordt aan het analyseren van arbeidsmarktuitkomsten op zowel korte als langere termijn.

Door mbo-bol niveau 2 opleidingen wat de vakinhoudelijke context betreft te verbreden wordt daarnaast de keuzeproblematiek bij de instroom in het mbo mogelijk verkleind. De definitieve studiekeuze kan worden uitgesteld voor jongeren die willen doorstromen naar een opleiding op een hoger niveau (zie hiervoor in meer detail ook Spanningsveld 2). De herziening van de kwalificatiestructuur (zie paragraaf 5.4) lijkt dan ook een stap in de goede richting te zetten door bijvoorbeeld de kwalificaties Helpende Zorg \& Welzijn, Medewerker facilitaire dienstverlening en Medewerker sport en recreatie samen te voegen in een kwalificatiedossier. Het is in deze context echter spijtig dat binnen de nieuwe kwalificatiestructuur slechts uiterst beperkt de mogelijkheid geboden wordt om een verbredend keuzedeel van een ander kwalificatiedossier te kiezen. Hierdoor wordt de keuze voor mogelijke vervolgopleidingen impliciet ingeperkt en wordt de flexibiliteit van jongeren die na het behalen van het diploma op niveau 2 de arbeidsmarkt op gaan onnodig begrensd. Experimenten met kwalificatiedossier-overschrijdende keuzedelen, gericht op kennismaking met vervolgopleidingen/beroepsbeelden van andere kwalificatiedossiers dienen dan ook een belangrijk punt op de agenda van de herziening van de kwalificatiedossiers te vormen.

Spanningsveld 2: Ombuigen versus beïnvloeden: een probleem van foutieve timing en verantwoordelijkheid?

In het verlengde van het eerste spanningsveld ligt spanningsveld 2, waarbij de timing en de verantwoordelijkheid van het School-Ex 2.0 onderdeel 'ombuigingsgesprekken'

34 De brede mbo-bol niveau 2 opleidingen kunnen dan aangevuld worden op dit niveau door mbo-bbl niveau 2 opleidingen die per definitie meer gericht op een bepaald beroep zijn. 
ter discussie staan. Met timing wordt daarbij het moment van ingrijpen in het studiekeuzeproces bedoeld. In het geval van School-Ex is de mbo-instellingen de partij die volledig verantwoordelijk is gesteld voor dit ingrijpen. Uit het onderzoek kwam echter naar voren dat het aannemelijk is dat het studiekeuzeproces van jongeren is afgerond op het moment dat zij zich voor een bepaalde opleiding hebben aangemeld. Hoewel dit niet betekent dat mbo-scholen geen verantwoordelijkheid (zouden moeten) hebben in het ingrijpen in het studiekeuzeproces, betekent dit wel dat mbo-scholen niet de volledige verantwoordelijkheid zouden moeten dragen voor een succesvol ingrijpen in het studiekeuzeproces zoals bedoeld in het School-Ex 2.o programma. ${ }^{35} \mathrm{Het}$ moment van de interventie (ombuigingsgesprek) ligt aan het einde van een lang studiekeuzeproces of zelfs, uitgedrukt in sporttermen, in de blessuretijd. Daarnaast vindt het ingrijpen plaats door een voor de jongere'nieuwe' coach, welke (onverwacht) een nieuwe tactiek (keuze voor een andere opleiding) in het spel brengt. Deze tactiek is mogelijk ook nog eens tegenstrijdig aan de tactiek die de jongere met eerdere coaches (bijvoorbeeld mentoren in het vmbo of ouders) besproken heeft. Om dit spanningsveld te doorbreken is een grondigere ingreep nodig dan een verdergaande oproep om ombuigingsgesprekken te gaan voeren. Een tweetal opties, welke interessant zijn om nader te onderzoeken zijn daarbij:

- Het aanbieden van bredere mbo-bol opleidingen niveau 2 (specifiek ter vervanging van de opleidingen met structureel slechte arbeidsmarktperspectieven), waarmee het keuzemoment voor een specifieke(re) opleiding wordt uitgesteld.

- Een verplichte vroegtijdige en brede vooraanmelding bij een mbo-instelling, waarmee mbo-instellingen sneller de rol van studiekeuzebegeleider op zich kunnen nemen.

De eerstgenoemde optie ligt in het verlengde van de optie zoals besproken bij spanningsveld 1. Bredere mbo-bol basisopleidingen op niveau 2 bieden de kans voor jongeren om tijdens de mbo-bol niveau 2 opleiding kennis te maken met verschillende werkvelden, en de bijbehorende vervolgopleidingen na het behalen van het niveau 2 diploma. Hierdoor wordt automatisch de definitieve studiekeuzeperiode verlengd en kan de mbo instelling het vertrouwen van de jongeren winnen, zijn/haar capaciteiten in kaart brengen en zijn/haar plannen voor de toekomst bespreken, voordat er getracht wordt om de studiekeuze van de jongere te beïnvloeden. Ook voor jongeren die na het behalen van een diploma op niveau 2 niet gaan doorleren kan dit een aantrekkelijke optie zijn zoals in spanningsveld 1 besproken, aangezien het hun flexibiliteit op de arbeidsmarkt naar verwachting zal verhogen.

Het verplicht stellen van een vroegtijdige en brede vooraanmelding bij een mbo-instelling (bijvoorbeeld aan het begin van het vierde leerjaar van het vmbo) geeft mbo-instel-

35 We negeren hierbij de vraag of de studiekeuze van jongeren door het inbrengen van arbeidsmarktperspectieven mogelijk is of niet. Op basis van het hier voorliggende onderzoek lijkt dit ten minste twijfelachtig gezien het feit dat jongeren op deze leeftijd nog slechts marginaal met hun arbeidsmarktkansen bezig zouden zijn. 
lingen de kans om (tijdig) een coachende rol te gaan spelen in het studiekeuzeproces. De vooraanmelding dient breed te zijn zodat dan bijvoorbeeld alvast in kaart gebracht kan worden in welke opleidingssector (bijvoorbeeld Zorg \&Welzijn of Techniek) de jongeren geïnteresseerd zijn. Hierdoor kan de brede vooraanmelding een belangrijke mijlpaal in het studiekeuzeproces worden waarbij de vmbo-scholier persoonlijk kennismaakt met de mbo-instelling. In het verdere verloop van het vierde leerjaar van het vmbo kan dan in nauwe samenwerking met de vmbo-school de coachende rol van de mbo-instelling uitgebreid worden en de studiekeuze nader gedefinieerd worden zodat een soepele overgang van vmbo naar mbo kan plaatsvinden. ${ }^{36}$

Ook hier geldt dat het belangrijk is om op korte termijn met een aantal experimenten te starten om zo de effecten van een verplichte vroege en brede aanmelding nader te kunnen analyseren.

\section{Spanningsveld 3: Opleiden voor arbeidsmarkt of voorkomen van uitval}

Het derde spanningsveld welke we kort bespreken is gebaseerd op de uitkomst dat ombuigen volgens scholen het gevaar met zich meebrengt dat jongeren gedemotiveerd raken en daardoor een hoger risico lopen om voortijdig uit te vallen. Hiermee zouden het 'School-Ex 2.o programma (ombuigingsgesprekken)' en de effecten ervan mogelijk haaks staan op de'Aanval op schooluitval'. Bovendien moet rekening gehouden worden met de financiële prikkels die de twee beleidsaanpakken kennen. Terwijl in het kader van de 'aanval op schooluitval' een financiële prikkel ingezet wordt om voortijdig uitval te voorkomen, kent het School-Ex 2.o programma geen financiële prikkel wat het 'ombuigen' of ten minste 'beïnvloeden' betreft van de studiekeuze van jongeren die in het mbo een opleiding willen gaan volgen. ${ }^{37}$

Op basis van bestaand onderzoek over voortijdig schooluitval is niet eenduidig vast te stellen of het invoeren van bredere mbo-bol niveau 2 opleidingen (ter vervanging van opleidingen met weinig arbeidsmarktperspectieven) ook (ten dele) voor dit spanningsveld een uitweg biedt. Aan de ene kant bieden bredere opleidingen, waarin bijvoorbeeld door keuzedelen flexibel en op individueel niveau tijdens de opleiding ingezoomd kan worden op vakinhoudelijk verschillende kwalificaties, weliswaar een mogelijke oplossing om uitval door 'verkeerde' studiekeuze te voorkomen. Aan de andere kant schuilt in het aanbieden van brede opleidingen het risico dat jongeren zich te weinig kunnen identificeren met bepaalde potentiële beroepen, waardoor hun motivatie mogelijk afneemt en de kans op uitval wordt vergroot. Afhankelijk van de individuele sterkte van de twee effecten kan een bredere opzet van mbo-bol niveau 2 opleiding dan ook tot een

36 De hier gepresenteerde reden voor de vroegtijdige vooraanmelding (mogelijkheid voor mbo-instelling om nadrukkelijk een coachende rol op te eisen) kan gezien worden als een aanvullende reden om de aanmeldingstermijn te vervroegen zoals recent door de minister van OCW voorgesteld in het kader van een verdere aanpak op voortijdig schooluitval.

37 De financiële middelen in het kader van het School-EX 2.0 programma zijn naar ratio van ingevulde exitformulieren onder de mbo instellingen verdeeld. Omvang van ombuigingsgesprekken of de manier waarop deze gevoerd zijn speelde daarbij geen rol. 
verhoogde dan wel verlaagde kans op voortijdig schooluitval op dit niveau leiden. In het geval van de eerste uitkomst kan dit beleidsmatig tot een verdergaand spanningsveld leiden: Is men bereid door het invoeren van bredere mbo-bol opleidingen de vervolgonderwijsrelevantie en de arbeidsmarktrelevantie van mbo-bol niveau 2 opleidingen te verbeteren ten koste van het terugdringen van voortijdig schooluitval?

\section{Spanningsveld 4: Consequenties voor instroom in mbo-bbl opleidingen}

Dit rapport richt zich vrijwel uitsluitend op opleidingen die in de beroepsopleidende leerweg (bol) aangeboden worden. De eerste drie spanningsvelden die zijn geïdentificeerd, zijn in deze leerweg doorgaans ook het meest voelbaar. Desondanks is het van belang om kort stil te staan bij eventuele consequenties van de voorgestelde opties voor (instroom in) opleidingen in de beroepsbegeleidende leerweg (bbl). Mbo-bol en mbo-bbl opleidingen gelden immers als communicerende vaten, waarbij in economisch moeilijke tijden jongeren die hun voorkeur voor een mbo-bbl opleiding door een afname in het aanbod aan mbo-bbl leerwerkplekken niet kunnen vervullen, de optie hebben om uit te wijken naar een qua inhoud vergelijkbare opleiding in het mbo-bol. Het (deels) verbreden van mbo-bol opleidingen en het vergroten van de nadruk op de vervolgonderwijsrelevantie bij mbo-bol opleidingen zal de alternatieven voor jongeren die 'hands on' in de beroepsbegeleidende leerweg hun opleiding willen volgen minder aantrekkelijk maken. Dit speelt geen rol wanneer de afname in het aanbod aan mbo-bbl leerwerkplekken van structurele aard is en een indicatie is van een structureel verslechterde arbeidsmarktrelevantie van deze mbo-bbl opleiding. Het grootste gevaar schuilt echter in de tijdelijke en conjunctuur gerelateerde verschuiving van mbo-bbl naar mbo-bol, zoals in de recente economische recessie. In plaats van 'hands on' moet een relatief grote groep jongeren nu de opleiding met 'de neus in de boeken' volgen, zonder dat hieraan een structurele wijziging in de arbeidsmarktrelevantie ten grondslag ligt. Hierdoor lopen we het risico dat de motivatie van deze jongeren afneemt en zij een grotere kans op voortijdig schooluitval hebben. Dit wordt mogelijk nog versterkt wanneer zij gedwongen worden in plaats van een relatief specifieke mbo-bbl opleiding te switchen naar een relatief brede mbo-bol opleiding.

Om te voorkomen dat door het verbreden van mbo-bol opleidingen een nieuw spanningsveld wordt gecreëerd, dient dan ook uitvoerig worden nagedacht over de manier waarop de opleidingscapaciteit van mbo-bbl opleidingen met een structureel goed arbeidsmarktperspectief in tijden van een economische malaise bij werkgevers in stand gehouden kan worden. Een anticyclische subsidie aan bedrijven kan hierbij een mogelijke oplossing bieden en als stimulans in magere tijden werken ${ }^{38}$ : hierbij wordt in tijden van economische bloei de subsidie verlaagd en in tijden van economische malaise de subsidie verhoogd. Dit kan zorgen voor een stabieler aanbod van mbo-bbl-plaatsen. Om lange discussies in tijden van terugvallende overheidsinkomsten te voorkomen, wordt

38 De auteurs zijn zich zeker bewust van dat a) de technische uitvoering van zo'n anticyclische subsidie uiterst gecompliceerd kan zijn en b) dat door de invoering van een anticyclische subsidie de overheid zal trachten het HR beleid van bedrijven te beïnvloeden. 
deze anticyclische subsidie idealiter voor een langere periode vastgesteld zodat zij als automatische stabilisator kan werken. Natuurlijk dient daarbij continue op basis van structurele arbeidsmarktrelevantie worden bepaald voor welke opleidingen anticyclische subsidies van toepassing zijn $^{39}$, zodat er voorkomen kan worden dat een conjunctureel probleem van een opleiding dat in een structureel probleem overgaat niet tot een structurele subsidie aan werkgevers gaat leiden waarmee zij structureel gesubsidieerde werknemers in dienst kunnen nemen onder de noemer van een mbo-bbl opleiding.

Op basis van de geïdentificeerde spanningsvelden kan puntsgewijs samengevat worden in welke richting in nabije toekomst verdergaande onderzoek nodig is:

- In het kader van macrodoelmatigheid dient naast arbeidsmarktrelevantie de vervolgonderwijsrelevantie van opleidingen in kaart gebracht te worden en nader geanalyseerd te worden welke gewichten aan deze twee 'relevanties' toegediend zouden moeten worden.

- Het is van belang om in de nabije toekomst te experimenteren met kwalificatiedossiers overschrijdende keuzedelen en het verbreden van de mbo-bol niveau 2 opleidingen waarvoor structureel weinig arbeidsmarktperspectief is.

- Experimenten met een verplichte vroegtijdige en brede vooraanmelding bij een mbo-instelling zijn van belang om vast te stellen of het daardoor mogelijk wordt dat mbo-instellingen hun coachende en sturende rol bij het studiekeuzeproces kunnen vergroten.

39 Hierbij dient ook rekening mee gehouden te worden dat sectoren, maar zeker ook individuele opleidingen, verschillen in de conjunctuurgevoeligheid en de volgtijdelijkheid waarmee zij geraakt worden in de conjunctuurcyclus. 



\section{LITERATUUR}

Corvers, F., Hoon de, M., Meng, C. (2014), Macrodoelmatigheid mbo: Inkadering arbeidsmarktperspectief, ROA-R-2014/1. Maastricht: Researchcentrum voor Onderwijs en Arbeidsmarkt

Eimers, T. (2012), Afwegingskader regionaal/sectoraal opleidingenaanbod mbo, Kenniscentrum

Beroepsonderwijs Arbeidsmarkt (KBA), Nijmegen.

Kamerstukken II, 2013-20626. Aanpak Jeugdwerkloosheid, brief van de ministers van SZW en OCW aan de Tweede Kamer, d.d. 05-03-2013

Meng, C.M., Verhagen, A.M.C., Korthals, R. \& Huigen, T.G. (2014). Evaluatie van het School Ex 2.0 Programma. De rol van studiekeuze- en exitgesprekken in het MBO (ROAR-2014/2). Maastricht: Researchcentrum voor Onderwijs en Arbeidsmarkt.

ROA (2013), Arbeidsmarktrelevantie van grote MBO-opleidingen, ROA-F-2013/1. Maastricht: Researchcentrum voor Onderwijs en Arbeidsmarkt

ROA (2014), Schoolverlaters tussen onderwijs en arbeidsmarkt 2013, ROA-R-2014/5. Maastricht: Researchcentrum voor Onderwijs en Arbeidsmarkt.

ROA (2015) , Schoolverlaters tussen onderwijs en arbeidsmarkt 2014, ROA-R-2015/3. Maastricht: Researchcentrum voor Onderwijs en Arbeidsmarkt.

Staatscourant (2013), Nr 24075, augustus 2013. 



\section{BIJLAGE 1}

Aanpak Jeugdwerkloosheid

In de brief van de ministers van SZW en OCW van maart 2013 wordt de Aanpak Jeugdwerkloosheid nader toegelicht. De doelstelling van de aanpak is daarbij zowel het bestrijden van de actuele jeugdwerkloosheid (en een verdere stijging daarin) evenals het voorkomen van toekomstige jeugdwerkloosheid. Onderstaand overzicht biedt een korte samenvatting van de Aanpak Jeugdwerkloosheid. 


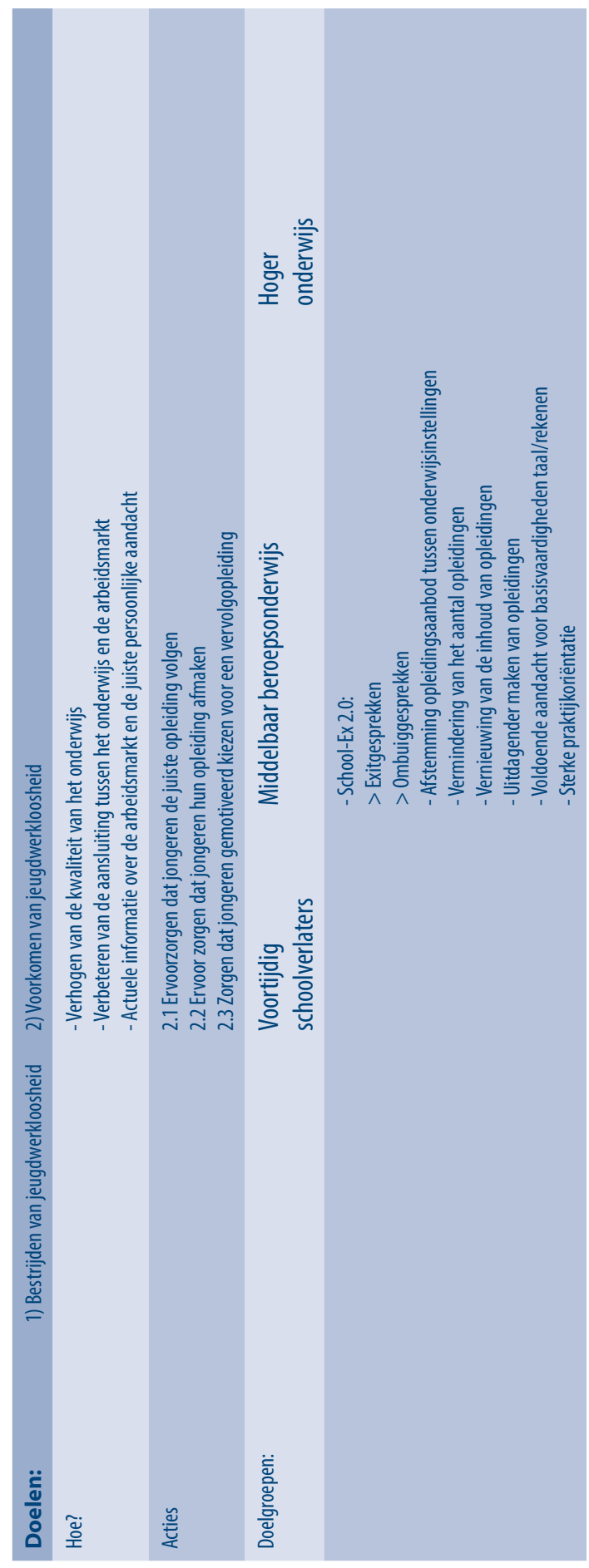

60 BIJLAGE 1 


\section{BIJLAGE 2}

Aantal vragenlijsten dat is verstuurd aan School-Ex contactpersonen en ingevuld door relevante actoren op mbo-scholen

\begin{tabular}{|l|l|l|l|l|} 
& $\begin{array}{l}\text { Administrief } \\
\text { Medewerker* }\end{array}$ & $\begin{array}{l}\text { Helpende Zorg \& } \\
\text { Welzijn* }\end{array}$ & Dierverzorging 2** & Totaal \\
\hline Aantal vragenlijsten verstuurd & 47 & 47 & 13 & 107 \\
\hline Aantal vragenlijsten ontvangen & 31 & 31 & 10 & 72 \\
\hline \begin{tabular}{l} 
Responspercentage \\
\hline * Twee roc's hebben elk twee vragenlijsten ontvangen, een ROC heeft vier vragenlijsten ontvangen \\
** Een AOC heeft twee vragenlijsten ontvangen
\end{tabular} & $66 \%$ & $77 \%$ & $67 \%$ \\
\hline
\end{tabular}





\section{BIJLAGE 3}

\section{Topiclist interviews}

- Introductie

- $\quad$ Toestemming vragen voor geluidsopname

- Voorstellen interviewers en korte uitleg van de aanleiding van het onderzoek

- Doel van het interview / te bespreken onderwerpen:

- Mogelijkheid en wenselijkheid van het beïnvloeden van het aantal instromende leerlingen

- Hoe worden arbeidsmarktperspectieven bepaald

- $\quad$ Functie respondent

- Reden voor het beïnvloeden van het aantal instromende leerlingen in 2014/2015

OF

- Reden dat er niet wordt geprobeerd om het aantal instromende leerlingen te beïnvloeden

- Indicatoren voor het vaststellen van arbeidsmarktperspectief

- Bijv. stages, zelf monitoren werkloosheid, prognoses (van wie?)

- Kenmerken van instromende leerlingen

- Zijn er "typische" Administratief Medewerker / Helpende Zorg \& Welzijn / Dierverzorging 2 leerlingen? (indicatie van generaliseerbaarheid)

- Kunnen alle aanmelders worden geplaatst?

- Indien Nee: Waar komt "overschot" terecht

- De (on)mogelijkheid van ombuigen

- Hoe stimuleer je iemand wat anders te studeren (eventueel hypothetisch)

- Context

- Beroepsbeeld van de aanmelders

- Rol van de ouders en vmbo in studiekeuze proces

- Doorstroom i.c.m. invoering Cascademodel 
- Doel van een opleiding / wanneer is een gediplomeerde succesvol

- Werkzaam, type werk, tevreden over opleiding, etc

- Lessen voor andere mbo-scholen

- Lessen van andere mbo-scholen 


\section{BIJLAGE 4}

SchoolverlatersInformatieSysteem: Een openbaar toegankelijke bron van data

Algemeen

De subsidiemiddelen beschikbaar gesteld door het Ministerie van Onderwijs, Cultuur en Wetenschap, het Ministerie van Economische Zaken en het Ministerie van Sociale Zaken en Werkgelegenheid maken de basisvoorziening mogelijk (dataverzameling, technisch databeheer en algemene methoden- en modellenstudies). De databestanden zijn daarbij vrij toegankelijk en maken daarmee een breed pallet van strategisch onderzoek mogelijk, van proefschriften, wetenschappelijke beleidsrelevante artikelen tot landelijke beleidsrapportages. De jaarlijkse databestanden afkomstig van het SchoolverlatersInformatieSysteem zijn beschikbaar via www.dans.knaw.nl. Via het Researchcentrum voor Onderwijs en Arbeidsmarkt kunnen onderzoekers eveneens kosteloos een Engelstalig trendbestand (metingen 1998 - 2014) opvragen. Voor ondersteuning bij het gebruik van de databestanden zijn de onderzoekers van het ROA bereikbaar via secretary-roa-sbe@maastrichtuniversity.nl.

Cijfers afkomstig van het SchoolverlatersInformatieSysteem zijn recent onder andere gebruikt voor ${ }^{32}$ :

- Studiekeuze 123 website

- Studie in cijfers

- Keuzegids MBO, Keuzegids HBO

- Onderwijsinspectie: De staat van het onderwijs - onderwijsverslag

- MBO raad: Feiten en cijfers

- ECBO: Het Nederlandse onderwijs geketend: Doorstroom in en tussen vo en mbo

- ECBO: De kleur van het middelbaar beroepsonderwijs: Een overzichtsstudie naar allochtonen in het mbo

- Inspectie der Rijksfinanciën: Productiviteit Onderwijs, Rapport brede heroverwegingen

- Innovatieplatform: Kennis en Innovatie Agenda 2011 - 2020

- SCP, Jaarrapport Integratie, 2013.

32 Voor rapportages van het ROA op basis van cijfers afkomstig van het S.choolverlatersInformatieSysteem, zie www.roa.nl. 
Website Kerncijfers Schoolverlatersonderzoeken:

https://roastatistics.maastrichtuniversity.nI/SISOnline/Home.aspx

Op de website Kerncijfers Schoolverlatersonderzoeken (https://roastatistics.maastrichtuniversity.nI/SISOnline/Home.aspx) zijn meerjarige landelijke statistieken te vinden over gediplomeerde schoolverlaters van het initiële onderwijs in Nederland. De cijfers zijn gebaseerd op de schoolverlatersonderzoeken van het ROA en hebben betrekking op de gediplomeerden van het AVO, VMBO, MBO en het HO. De kerncijfers die gepresenteerd worden geven een inzicht in de gevolgde studie, het vervolgonderwijs en de intrede van de schoolverlaters op de arbeidsmarkt.

De website is te raadplegen vanuit twee invalshoeken: naar onderwijsindeling en naar kernindicator. De invalshoek naar onderwijs laat alle kerncijfers voor een bepaalde onderwijsindeling zien. Hierbij kan gekozen worden voor onderwijsniveaus, onderwijssectoren en individuele opleidingen. Daarnaast is er de mogelijkheid om een keuze te maken voor voltijd, deeltijd of duale opleidingsvarianten. De invalshoek naar indicator laat voor alle onderwijsniveaus, - sectoren dan wel opleidingen de informatie over één gekozen indicator zien. Zowel in het menu als in de overzichtstabellen zijn de kernindicatoren naar een vijftal categorieën ingedeeld:

- algemene achtergrondkenmerken

- gevolgde opleiding

- oordeel over de gevolgde opleiding

- kenmerken vervolgonderwijs

- arbeidsmarktindicatoren en baankenmerken

De cijfers worden telkens weergegeven voor de laatste vijf meetjaren en worden jaarlijks geupdate rond de tijd dat het landelijk rapport 'Schoolverlaters tussen Onderwijs en Arbeidsmarkt' uitkomt.

De website biedt daarnaast uitgebreide informatie over de methodologische aanpak van het Schoolverlatersinformatiesysteem (SIS) alsmede een verantwoording van de respons. 